\title{
Technical English for renewable energy
}

Open Educational Resources for online course of technical English for renewable energy

Author:

Rozália Szabó
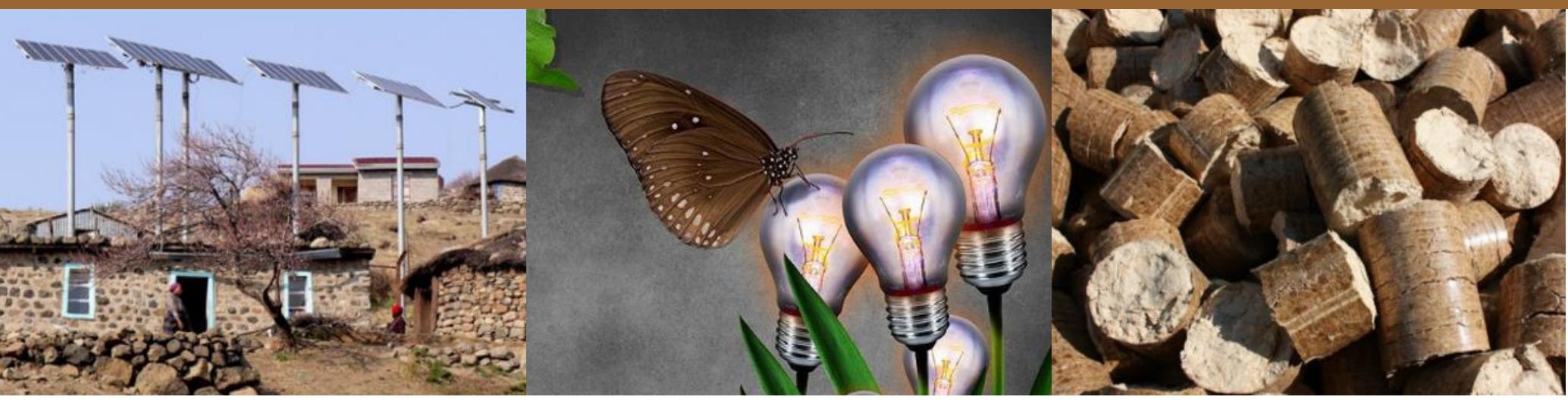

*ै INZRURAL

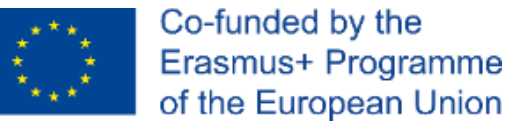

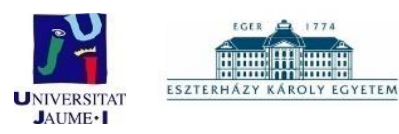

Universitatea
"Vasile Alecsandri"
din Bacau

$4 \mathrm{mans}$ 
Place and year of edition:

Gyöngyös (Hungary), 2016

Author:

Rozália Szabó

cc) (i) (2) $C \mathrm{CCBY}-\mathrm{NC}-\mathrm{SA}$

This licence allows others remix, transform, or build upon the material without commercial purposes, giving appropriate credit and distributing their contributions under the same license as the original.

DOI: http://dx.doi.org/10.6035/IN2RURAL.2016.08

The PDF version of this document is available in:

http://in2rural.ub.ro/, http://in2rural.uji.es/ and http://repositori.uji.es/xmlui/handle/10234/154485

The European Commission support for the production of this publication does not constitute an endorsement of the contents which reflects the views only of the authors, and the Commission cannot be held responsible for any use which may be made of the information contained therein. 


\section{TABLE OF CONTENTS}

$\begin{array}{lr}\text { Technical English glossary for renewable energy } & 4\end{array}$

Unit 1. Renewable energy and rural development - Part 1

$\begin{array}{ll}\text { Unit 2. Renewable energy and rural development - Part } 2 & 23\end{array}$

Unit 3. Renewable energy and rural development - Part 3

Unit 4. Photovoltaic energy - Part 1

$\begin{array}{ll}\text { Unit 5. Photovoltaic energy - Part } 2 & 37\end{array}$

Unit 6. Photovoltaic energy - Part 3 42

Unit 7. Biomass - Part $1 \quad 46$

Unit 8. Biomass - Part 2 52

Unit 9. Biomass - Part $3 \quad 56$

Unit 10. Wind energy - Part 1

Unit 11. Wind energy - Part 2

$\begin{array}{ll}\text { Unit 12. Wind energy - Part } 3 & 68\end{array}$ 


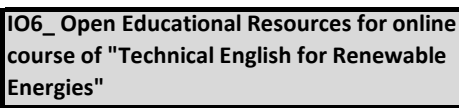

\section{TECHNICAL ENGLISH GLOSSARY FOR RENEWABLE ENERGY

TECHNICAL ENGLISH GLOSSARY FOR
RENEWABLE ENERGY

\begin{tabular}{|c|c|}
\hline technical term & definition \\
\hline A & See Ampere. \\
\hline AAU & See Assigned Amount Unit. \\
\hline absorbent & $\begin{array}{l}\text { a material that extracts one or more substances from a fluid medium on contact, and which changes } \\
\text { physically and/or chemically in the process }\end{array}$ \\
\hline absorber & $\begin{array}{l}\text { the component of a solar thermal collector that absorbs solar radiation and converts it to heat, or, as } \\
\text { in a solar photovoltaic device, the material that readily absorbs photons to generate charge carriers }\end{array}$ \\
\hline absorption & the passing of a substance or force into the body of another substance \\
\hline absorption chiller & a type of air cooling device that uses absorption cooling to cool interior spaces \\
\hline absorption coefficient & the degree to which a substance will absorb solar energy \\
\hline $\mathrm{AC}$ & See alternating current. \\
\hline accumulator & a component of a heat pump that stores liquid and keeps it from flooding the compressor \\
\hline acid rain & $\begin{array}{l}\text { precipitation that has become acidic (low } \mathrm{pH}) \text { due to the emission of sulfur oxides from fossil fuel } \\
\text { burning power plants }\end{array}$ \\
\hline active cooling & the use of mechanical heat pipes or pumps to carry heat by circulating heat transfer fluids \\
\hline active power & The power in Watts used by a device to produce useful work. Also called input power. \\
\hline active solar heater & $\begin{array}{l}\text { a solar water or space-heating system that uses pumps or fans to circulate the fluid from the solar } \\
\text { collectors to a storage tank subsystem }\end{array}$ \\
\hline active solar thermal system & $\begin{array}{l}\text { a system that traps solar energy with collectors and uses an electromechanical subsystem to move } \\
\text { that energy to its point of intended use for water heating, space heating, pool heating, industrial } \\
\text { process heat, electrical generation and space cooling }\end{array}$ \\
\hline adjustable speed drive & $\begin{array}{l}\text { an electronic device that controls the rotational speed of motor-driven equipment such as fans, } \\
\text { compressors and pumps by adjusting the frequency of the voltage applied to the motor }\end{array}$ \\
\hline adobe & $\begin{array}{l}\text { A traditional material used for building houses. It is made from clay, straw and water, formed into } \\
\text { blocks and dried in the sun. }\end{array}$ \\
\hline aerated lagoon & $\begin{array}{l}\text { in wastewater treatment or livestock facilities, a shallow pond used to store wastewater where } \\
\text { sunlight and biological activity decompose the waste }\end{array}$ \\
\hline aerobic bacteria & $\begin{array}{l}\text { Microorganisms that require oxygen to live. They contribute to the decomposition of organic material } \\
\text { in composting systems. }\end{array}$ \\
\hline air collector & a type of solar collector in which air is heated in solar heating systems \\
\hline air conditioner & a device for controlling the temperature and humidity of the air in an interior space \\
\hline air diffuser & an air distribution outlet which mixes room air with conditioned air \\
\hline air pollution & $\begin{array}{l}\text { the emission of contaminants into the air in concentrations that prevent the normal dispersive ability } \\
\text { of the air, and that interfere with biological processes }\end{array}$ \\
\hline air pollution & $\begin{array}{l}\text { the presence of contaminants or pollutant substances in the air that interfere with human health or } \\
\text { welfare, or produce other harmful environmental effects }\end{array}$ \\
\hline air register & the part of a combustion device that controls the amount of air entering the combustion chamber \\
\hline air retarder / air barrier & $\begin{array}{l}\text { a material or structural element that prevents air flow through a building's walls, while allowing water } \\
\text { to easily diffuse }\end{array}$ \\
\hline air-source heat pump & $\begin{array}{l}\text { A heat pump that transfers heat from outdoor air to indoor air during the heating season, and works } \\
\text { in reverse during the cooling season. The system is also called an air-to-air system. }\end{array}$ \\
\hline air-to-water heat pump & a heat pump that transfers heat in outdoor air to water for space or water heating \\
\hline airfoil & $\begin{array}{l}\text { an airfoil (in American English) or aerofoil (in British English) is the cross-section profile of the leeward } \\
\text { side of a wind generator blade }\end{array}$ \\
\hline albedo & The ratio of light reflected by a surface to the light falling on it. Also called reflection coefficient. \\
\hline algae & primitive plants, usually aquatic, capable of synthesizing their own food by photosynthesis \\
\hline algal biofuel / algae fuel & an alternative to liquid fossil fuels that uses algae as its source of energy-rich oils \\
\hline alternating current $(\mathrm{AC})$ & $\begin{array}{l}\text { an electric current in which the flow of electric charge periodically changes direction between positive } \\
\text { and negative sides }\end{array}$ \\
\hline alternative fuels & $\begin{array}{l}\text { Fuels other than conventional fuels (fossil fuels, coal, natural gas, nuclear materials). Examples } \\
\text { include biodiesel, methanol, ethanol, hydrogen, vegetable oil and other biomass sources. }\end{array}$ \\
\hline alternator & $\begin{array}{l}\text { A device that produces alternating current (AC) electricity from the rotation of a shaft. It is used in } \\
\text { wind and water turbines to generate electricity. }\end{array}$ \\
\hline altitude angle & $\begin{array}{l}\text { The angle of the sun above the horizon, measured in degrees. In winter, the sun is at a low solar } \\
\text { altitude, while in the summer, the solar altitude is high. }\end{array}$ \\
\hline ammeter & an instrument that measures the electric current in a circuit in amperes (A) \\
\hline amorphous semiconductor & a non-crystalline semiconductor material with no long-range order \\
\hline
\end{tabular}




\begin{tabular}{|c|c|}
\hline amorphous silicon & $\begin{array}{l}\text { an alloy of silica and hydrogen that can be deposited in thin-film layers to produce thin-film } \\
\text { photovoltaic cells on glass, metal, or plastic bases }\end{array}$ \\
\hline $\mathrm{amp}$ & See Ampere. \\
\hline amp-hour / ampere-hour & a measure of the flow of current (in amperes) over one hour \\
\hline ampacity & $\begin{array}{l}\text { The highest safe amount of electrical current through conductors, overcurrent devices, or other } \\
\text { electrical equipment. Ampacity is determined by the cross-sectional area and the material of the } \\
\text { conductor. }\end{array}$ \\
\hline Ampere (Amp or $\mathrm{A})$ & $\begin{array}{l}\text { A unit of measure for an electrical current: the amount of current that flows in a circuit at an } \\
\text { electromotive force of one Volt and at a resistance of one Ohm. Abbreviations: A or amp. }\end{array}$ \\
\hline ampere-hour meter & an instrument that monitors electron flow over time \\
\hline amplitude & $\begin{array}{l}\text { the maximum and minimum voltage attained by an alternating or pulsed current in each complete } \\
\text { cycle or pulse of that current }\end{array}$ \\
\hline anaerobic digestion & $\begin{array}{l}\text { A process that produces methane. Natural bacteria are used to decompose organic matter in the } \\
\text { absence of oxygen in closed reactors. Gas suitable for power production is produced, and possibly } \\
\text { troublesome wastes (such as those at sewage treatment plants or feedlots) are turned to usable } \\
\text { compost. }\end{array}$ \\
\hline anaerobic lagoon & $\begin{array}{l}\text { a waste treatment basin in the ground filled with liquid animal waste that undergoes anaerobic } \\
\text { respiration }\end{array}$ \\
\hline anemometer & a device that measure the speed of the wind \\
\hline angle of attack & the angle of relative air flow to the blade chord of a wind turbine \\
\hline angle of incidence & $\begin{array}{l}\text { the angle between the sun's rays and a line perpendicular to the active surface of a solar module or } \\
\text { collector, in degrees }\end{array}$ \\
\hline angle of inclination & the angle that a solar collector or PV module is positioned above horizontal \\
\hline annual fuel utilization efficiency (AFUE) & the measure of annual efficiency of a residential heating boiler \\
\hline annual load fraction & the fraction of annual energy demand supplied by a solar system \\
\hline annual solar savings & $\begin{array}{l}\text { the energy saved by a solar building attributable to its solar feature relative to the energy } \\
\text { requirements of a non-solar building }\end{array}$ \\
\hline anode & $\begin{array}{l}\text { The electrode within a battery cell that undergoes the chemical process of oxidation. Electrically, the } \\
\text { anode is the positive terminal of the cell. In a water heater, the anode is an aluminum or magnesium } \\
\text { sacrificial rod that is installed within steel tanks to prevent corrosion. }\end{array}$ \\
\hline anti-reflection coating & $\begin{array}{l}\text { a thin layer applied to a photovoltaic cell surface that reduces light reflection and increases light } \\
\text { transmission }\end{array}$ \\
\hline antifreeze solution & $\begin{array}{l}\text { a fluid, such as methanol, added to vehicle engine coolant, or used in solar heating system heat } \\
\text { transfer fluids, to protect the system from freezing }\end{array}$ \\
\hline aperture & the area of a solar collector through which solar radiation is admitted and directed to the absorber \\
\hline apparent day & $\begin{array}{l}\text { a solar day, or apparent solar time, which is the interval between two successive returns of the Sun to } \\
\text { the local meridian }\end{array}$ \\
\hline apparent power & $\begin{array}{l}\text { The voltage-ampere requirement of a device designed to convert electric energy to a non-electrical } \\
\text { form. It is expressed in kilovolt-amperes (VA). }\end{array}$ \\
\hline array & a number of photovoltaic modules electrically connected to produce a single electrical output \\
\hline ash & the non-combustible residue of a combusted substance \\
\hline ASHP & See air-source heat pump \\
\hline Assigned Amount Unit (AAU) & $\begin{array}{l}\text { Under the Kyoto Protocol, member countries have AAUs, i.e. emission permits or carbon credits, } \\
\text { which, if unused, can be traded with other member countries. One AAU is one metric ton of CO2e. } \\
\text { See also metric ton and CO2e. }\end{array}$ \\
\hline asynchronous generator & an electric generator that produces alternating current that matches an existing power source \\
\hline atmospheric pressure & the pressure of the air at sea level \\
\hline attic vent & $\begin{array}{l}\text { a passive or mechanical device to ventilate an attic space, primarily to reduce heat buildup and } \\
\text { moisture condensation }\end{array}$ \\
\hline automatic / remote meter reading system & $\begin{array}{l}\text { a system that records the consumption of electricity, water, gas, etc. and sends the data to a central } \\
\text { data accumulation device }\end{array}$ \\
\hline automatic damper & a device that cuts off the flow of hot or cold air to or from a room as controlled by a thermostat \\
\hline availability factor & $\begin{array}{l}\text { a percentage that represents the number of hours that a generating unit is available to produce } \\
\text { power in a given period, compared to the number of hours in the period }\end{array}$ \\
\hline available heat & the amount of heat energy that may be converted into useful energy from a fuel \\
\hline average velocity & the mean wind speed over a specified period of time \\
\hline avoided cost & $\begin{array}{l}\text { the incremental cost to an electric power producer to generate or purchase a unit of electricity of } \\
\text { capacity or both }\end{array}$ \\
\hline axial flow turbine & a turbine in which the flow of a steam or gas is essentially parallel to the rotor axis \\
\hline axis & in geometry, an axis is a straight line around which an object may rotate \\
\hline azimuth & $\begin{array}{l}\text { The angle between true south and a point on the horizon. It is measured in degrees east or west of } \\
\text { true south. }\end{array}$ \\
\hline backup energy system & a reserve appliance, for example a stand-by generator for a home or commercial building \\
\hline bagasse & $\begin{array}{l}\text { Plant residue (as of sugarcane) left after the juice has been extracted. It is a fibrous material suitable } \\
\text { for producing energy through burning. }\end{array}$ \\
\hline balance of systems (BOS) & parts of a photovoltaic system other than the photovoltaic array or other generating equipment \\
\hline balancing & $\begin{array}{l}\text { Adjusting the weight and weight distribution of wind turbine blades through two axes in order to } \\
\text { make them balanced. Unbalanced blades create damaging vibration. }\end{array}$ \\
\hline base load & the minimum load of a power plant \\
\hline base load capacity & the power output of a power plant that can be continuously produced \\
\hline base load demand & the minimum demand experienced by a power plant \\
\hline
\end{tabular}




\begin{tabular}{|c|c|}
\hline base load power plant & $\begin{array}{l}\text { a power plant that is normally operated to generate a base load, and that usually operates at a } \\
\text { constant load }\end{array}$ \\
\hline batch solar hot water heater & $\begin{array}{l}\text { A batch heater consists of one or more storage tanks placed in an insulated box that has a glazed side } \\
\text { facing the sun. It is mounted on the ground or on the roof. Also known as bread box system or } \\
\text { integral collector storage system }\end{array}$ \\
\hline battery capacity & $\begin{array}{l}\text { The total maximum charge that can be withdrawn from a battery under specific conditions including } \\
\text { discharge rate, temperature, state of charge, age and cutoff voltage. It is expressed in ampere-hours. } \\
\text { See also ampere-hour. }\end{array}$ \\
\hline battery cell & $\begin{array}{l}\text { the simplest operating unit in a storage battery, consisting of one or more positive electrodes or } \\
\text { plates, electrolyte, one or more negative electrodes or plates, separators, a container and posts or } \\
\text { other terminals }\end{array}$ \\
\hline battery cycle life & $\begin{array}{l}\text { the number of cycles that a cell or battery can undergo before failing to meet its specified capacity or } \\
\text { efficiency performance criteria }\end{array}$ \\
\hline battery life & $\begin{array}{l}\text { the period during which a cell or battery is capable of operating above a specified capacity or } \\
\text { efficiency performance level }\end{array}$ \\
\hline beam radiation & solar radiation that is not scattered by dust or water droplets \\
\hline best practice & $\begin{array}{l}\text { examples of the most successful and transferable projects (or initiatives), selected } \\
\text { from the good practice examples to disseminate innovation and lessons learned from } \\
\text { implementation }\end{array}$ \\
\hline Betz limit & $\begin{array}{l}\text { According to Betz's law, no wind turbine can convert more than } 59.3 \% \text { of the kinetic energy of the } \\
\text { wind into mechanical energy turning a rotor. This is known as the Betz limit. }\end{array}$ \\
\hline bimetal & $\begin{array}{l}\text { two metals of different coefficients of expansion welded together so that the piece will bend in one } \\
\text { direction when heated, and in the other direction when cooled, and can be used to open or close } \\
\text { electrical circuits, as in thermostats }\end{array}$ \\
\hline binary cycle & $\begin{array}{l}\text { The combination of two power plant turbine cycles using two different working fluids for power } \\
\text { production. The waste heat from the first turbine cycle provides the heat energy for the operation of } \\
\text { the second turbine, thus providing higher overall system efficiency. }\end{array}$ \\
\hline bioconversion & $\begin{array}{l}\text { the conversion of one form of energy into another by the action of plants or microorganisms, such as } \\
\text { the conversion of biomass to ethanol, methanol or methane }\end{array}$ \\
\hline biodegradable & able to decay naturally and in a way that is not harmful to the environment \\
\hline biodegradable municipal waste (BMW) & waste that can be degraded in a way that is not harmful to the environment \\
\hline biodiesel & $\begin{array}{l}\text { An alternative fuel produced from used cooking oil, plant oils or animal fats. When combined with } \\
\text { petroleum diesel, the biodiesel blend can be used in most diesel engines. It is biodegradable and non- } \\
\text { toxic. }\end{array}$ \\
\hline biodiversity & The variety of life in the world or in a particular habitat or ecosystem. See also habitat and ecosystem. \\
\hline bioenergy & $\begin{array}{l}\text { Renewable energy produced from organic matter. It may be used directly as a fuel or processed into } \\
\text { liquids and gases. }\end{array}$ \\
\hline biofuel & biomass converted directly to energy by burning, or converted to liquid or gaseous fuels \\
\hline biofuels feedstock & $\begin{array}{l}\text { Any material that is used to make biofuels. Examples include corn, sugarcane, soybeans and palm. See } \\
\text { also biofuel. }\end{array}$ \\
\hline biogas & $\begin{array}{l}\text { Gas containing methane and carbon dioxide. It results from the action of microorganisms on organic } \\
\text { materials such as landfills. Also called biomass gas. }\end{array}$ \\
\hline biogasification & the process of decomposing biomass with anaerobic bacteria to produce biogas \\
\hline biomass & $\begin{array}{l}\text { Any organic matter available on a renewable basis, such as wood, agricultural crops or wastes, and } \\
\text { municipal wastes, when used as a source of fuel or energy. Biomass can be burned directly or } \\
\text { converted to biofuels. See also municipal waste and biofuel. }\end{array}$ \\
\hline biomass gasification & $\begin{array}{l}\text { The conversion of biomass into a gas, by biogasification or thermal gasification. See also } \\
\text { biogasification and thermal gasification. }\end{array}$ \\
\hline biomass waste & $\begin{array}{l}\text { Organic non-fossil material of biological origin that is a byproduct or a discarded product. It includes } \\
\text { municipal solid waste from biogenic sources, landfill gas, sludge water, agricultural crop byproducts, } \\
\text { straw, etc. However, it excludes wood and wood-derived fuels, biodiesel, fuel ethanol and biofuels } \\
\text { feedstock. }\end{array}$ \\
\hline biomethanization & See biogasification. \\
\hline biophotolysis & $\begin{array}{l}\text { the action of light on a biological system that results in the dissociation of a substrate, usually water, } \\
\text { to produce hydrogen }\end{array}$ \\
\hline biopower & the power (heat or electricity) produced from biomass resources \\
\hline black liquor & $\begin{array}{l}\text { Alkaline spent liquor, which is a byproduct of the paper production process. It is removed from the } \\
\text { digesters in the process of chemically pulping wood. See also digester. }\end{array}$ \\
\hline blackbody & an ideal substance that absorbs all radiation falling on it, and reflecting nothing \\
\hline blade & See wind generator blade. \\
\hline BMW & See biodegradable municipal waste. \\
\hline boiler & $\begin{array}{l}\text { a tank where heat produced from the combustion of fuels such as natural gas, fuel oil, or coal is used } \\
\text { to generate hot water or steam for applications ranging from building space heating to electric power } \\
\text { production or industrial process heat }\end{array}$ \\
\hline boiler feedwater & $\begin{array}{l}\text { the water that is forced into a boiler to take the place of that which is evaporated in the generation of } \\
\text { steam }\end{array}$ \\
\hline boiler pressure & the pressure of the steam or water in a boiler, usually expressed in bars \\
\hline bone dry / oven dry & having zero moisture content (e.g. solid biomass fuel, such as wood) \\
\hline boron & the chemical element commonly used as the dopant in solar photovoltaic device or cell material \\
\hline brake / braking system & a device used to stop a wind turbine, which can be either mechanical or electric \\
\hline bread box system & See batch solar hot water heater and integral collector storage system \\
\hline brownfield & $\begin{array}{l}\text { a former industrial or commercial site where future use is affected by real or perceived environmental } \\
\text { contamination }\end{array}$ \\
\hline brushes & $\begin{array}{l}\text { devices usually made of carbon-graphite for transferring power to or from a rotating object of an } \\
\text { electric motor, alternator or generator }\end{array}$ \\
\hline building energy ratio & the space-conditioning load of a building \\
\hline
\end{tabular}




\begin{tabular}{|c|c|}
\hline building envelope & $\begin{array}{l}\text { The structural elements (walls, roof, floor, foundation) of a building that encloses conditioned space. } \\
\text { Also known as building shell. }\end{array}$ \\
\hline building heat-loss factor & a measure of the heating requirements of a building expressed in kWh per degree day \\
\hline building orientation & the relationship of a building to true south, as specified by the direction of its longest axis \\
\hline building overall heat loss rate & $\begin{array}{l}\text { the overall rate of heat loss from a building by means of transmission plus infiltration, expressed in } \\
\mathrm{kW} \text {, per degree temperature difference between the inside and outside }\end{array}$ \\
\hline burner capacity & $\begin{array}{l}\text { The maximum heat output released by a burner with a stable flame and satisfactory combustion. It is } \\
\text { expressed in } \mathrm{kW} \text {. }\end{array}$ \\
\hline burning point & the temperature at which a material ignites \\
\hline bus & See electrical bus. \\
\hline busbar & $\begin{array}{l}\text { The power conduit of an electric power plant. It is also the starting point of the electric transmission } \\
\text { system. }\end{array}$ \\
\hline cage & $\begin{array}{l}\text { the part of an electric motor composed of solid bars (usually aluminum or copper) arranged in a circle } \\
\text { and connected to continuous rings at each end }\end{array}$ \\
\hline capability & $\begin{array}{l}\text { the maximum load that a generating unit, power plant or other electrical apparatus can carry under } \\
\text { specified conditions for a given period of time, without exceeding its approved limits of temperature } \\
\text { and stress }\end{array}$ \\
\hline capacitance & $\begin{array}{l}\text { a measure of the electrical charge of a capacitor consisting of two plates separated by an insulating } \\
\text { material }\end{array}$ \\
\hline capacitor & $\begin{array}{l}\text { an electrical device that adjusts the leading current of an applied alternating current to balance the } \\
\text { lag of the circuit to provide a high power factor }\end{array}$ \\
\hline capacity & the maximum load a generating unit, generating station, or other electrical apparatus is rated to carry \\
\hline capacity factor & $\begin{array}{l}\text { the ratio of the electrical energy produced by a generating unit relative to the electrical energy that } \\
\text { could have been produced at continuous full power operation during the same period of time }\end{array}$ \\
\hline capacity value & $\begin{array}{l}\text { The percentage of conventional generation that can be displaced by wind generation. Sometimes also } \\
\text { called capacity credit. }\end{array}$ \\
\hline carbon footprint & $\begin{array}{l}\text { the total emissions of greenhouse gases in carbon equivalents from whichever source is being } \\
\text { measured }\end{array}$ \\
\hline carbon neutral & $\begin{array}{l}\text { through carbon offsetting, organisations or individuals that counterbalance the emissions they } \\
\text { produce make themselves carbon neutral }\end{array}$ \\
\hline carbon offsetting & $\begin{array}{l}\text { The process of reducing greenhouse gas emissions by purchasing credits from others through carbon } \\
\text { trading schemes. See also EU ETS. }\end{array}$ \\
\hline carbon sink & $\begin{array}{l}\text { a place that is able to absorb carbon dioxide from the atmosphere, such as forests, croplands and } \\
\text { grazing lands }\end{array}$ \\
\hline carbon stocks & $\begin{array}{l}\text { the amount of carbon stored in biological and physical systems including trees, agricultural crops, } \\
\text { wood and paper products and other terrestrial biosphere sinks, soils, oceans, and sedimentary and } \\
\text { geological sinks }\end{array}$ \\
\hline carcinogen & any substance capable of causing cancer \\
\hline cast silicon & $\begin{array}{l}\text { Used in photovoltaic cells. It is crystalline silicon obtained by pouring pure molten silicon into a } \\
\text { vertical mould and sawed into wafers for further fabrication into photovoltaic cells. }\end{array}$ \\
\hline cathode & $\begin{array}{l}\text { The electrode within a battery cell that undergoes the chemical process of reduction. Electrically, the } \\
\text { cathode is the negative terminal of the cell. }\end{array}$ \\
\hline CDE & carbon-dioxide equivalent \\
\hline $\begin{array}{l}\text { central tower power plant / solar power } \\
\text { tower }\end{array}$ & a type of solar furnace that uses a tower with movable mirrors to receive the focused sunlight \\
\hline charcoal & $\begin{array}{l}\text { a material formed from the incomplete combustion or destructive distillation of organic material in a } \\
\text { kiln or retort, and having a high energy density, being nearly pure carbon }\end{array}$ \\
\hline charge controller & $\begin{array}{l}\text { an electronic device that regulates the electrical charge stored in batteries so that unsafe, overcharge } \\
\text { conditions for the batteries are avoided }\end{array}$ \\
\hline chemical vapour deposition & $\begin{array}{l}\text { a chemical process used to produce high quality, high-performance, solid materials. It is also a } \\
\text { method of depositing thin semiconductor films used to make certain types of solar photovoltaic } \\
\text { devices }\end{array}$ \\
\hline chord & the width of a wind turbine blade at a given point along the length \\
\hline clean power & $\begin{array}{l}\text { Usually defined as power from renewable energy that comes from wind, solar, biomass energy, etc. } \\
\text { However, there are various definitions of clean resources. }\end{array}$ \\
\hline clean power generator & $\begin{array}{l}\text { a company or other organisational unit that produces electricity from sources that are thought to be } \\
\text { environmentally cleaner than traditional sources }\end{array}$ \\
\hline $\begin{array}{l}\text { cleavage of lateral epitaxial films for transfer } \\
\text { (CLEFT) }\end{array}$ & a process for making inexpensive Gallium Arsenide photovoltaic cells \\
\hline CLEFT & See cleavage of lateral epitaxial films for transfer. \\
\hline climate change & $\begin{array}{l}\text { all forms of significant changes in the earth's climate, including global warming and the frequent } \\
\text { occurrence of extreme weather conditions }\end{array}$ \\
\hline closed-loop biomass & $\begin{array}{l}\text { Any organic matter from a plant which is planted for the exclusive purpose of being used to produce } \\
\text { energy. It does not include wood or agricultural wastes. }\end{array}$ \\
\hline closed-loop geothermal heat pump system & a system that circulates a solution of water and antifreeze through a series of sealed loops of piping \\
\hline CMG & compressed methane gas \\
\hline CNG & compressed natural gas \\
\hline co-firing & $\begin{array}{l}\text { the burning of mixed fuels (usually refers to burning biomass with fossil fuel in a coal-fired power } \\
\text { station) }\end{array}$ \\
\hline co-generation & $\begin{array}{l}\text { the generation of electricity or shaft power by an energy conversion system and the concurrent use of } \\
\text { rejected thermal energy from the conversion system as an auxiliary energy source }\end{array}$ \\
\hline $\mathrm{CO} 2$ & carbon dioxide \\
\hline $\mathrm{CO} 2 \mathrm{e}$ & equivalent carbon dioxide \\
\hline coal bed methane / CBM & gas actively extracted from coal seams \\
\hline
\end{tabular}


coefficient of heat transmission (U-value) coefficient of performance

collector

collector efficiency

collector fluid

collector tilt

combined cycle power plant combined heat and power (CHP) plant

combustion

compost

composting

compound paraboloid collector

concentrating solar collector

condensing furnace

Conservation Design Development

conservation management

conservation subdivision

constant-speed wind turbine

contamination

convection

convectional heat pump

cooling pond

cooling tower

Corporate Social Responsibility

coulomb

cradle-to-cradle

cradle-to-grave

crystalline silicon photovoltaic cell CSR

cube law

culvert

cut-in-speed

cut-out-speed

cycling loss

cyclone burner

days of autonomy

DC

declination

decomposition

deep discharge

deep-well injection

degree day

degree hour

dendrite

dependable capacity

desiccation a value that describes the ability of a material to conduct heat

the measure of how many units of heat are generated per unit of electricity used

the component of a solar energy heating system that collects solar radiation, and that contains components to absorb solar radiation and transfer the heat to a heat transfer fluid the ratio of solar radiation captured and transferred to the collector fluid

the fluid, either liquid or air, used to absorb solar energy and transfer it for direct use, indirect heating of interior air or domestic water, and/or to a heat storage medium

the angle that a solar collector is positioned from horizontal

An electric generating technology in which electricity is produced from otherwise lost waste heat exiting from one or more gas turbines. The exiting heat is routed to a conventional boiler or to a heat recovery steam generator for utilization by a steam turbine in the production of electricity. Such designs increase the efficiency of the electric generating unit.

a power plant that uses two thermodynamic cycles to achieve higher overall system efficiency a power plant that produces both heat and electricity from a single heat source

rapid chemical combination of a substance with oxygen that involves the production of heat and light a mixture of organic matter that has decayed or has been digested by organisms, used to improve soil structure and provide nutrients

the process of degrading organic material by microorganisms in aerobic conditions a form of solar concentrating collector that does not track the sun

a solar collector that uses reflective surfaces to concentrate sunlight onto a small area, where it is absorbed and converted to heat or, in the case of solar photovoltaic devices, into electricity

a type of heating appliance that extracts so much of the available heat content from a combusted fuel that the moisture in the combustion gases condenses before it leaves the furnace

a type of development in which developers concentrate homes on a small portion of the developable land, leaving a large part of the site in its natural state

Formalized actions that includes realistic and integrated approraches to maintain existing genetic

diversity and viable populations of flora and fauna in the wild in order to maintain biological interactions, ecological processess, and function

residential or mixed-use development in which a significant portion of the site is set aside as undivided, permanently protected open space, with houses clustered on the remainder of the property

a wind turbine that operates at a constant rotor revolutions per minute and is optimized for energy

capture at a given rotor diameter at a particular speed in the wind power curve

introduction of microorganisms, chemicals, toxic substances, wastes or wastewater into the water, air and soil in concentrations that make them unfit for their next intended use

the transfer of heat by means of air currents

a type of heat pump which is also known as an air-to-air system

a body of water used to cool the water that is circulated in an electric power plant

a structure used to cool power plant water

a business plan to reduce its negative impact on the environment, economy and society a unit for the quantity of electricity transported in 1 second by a current of 1 ampere

the life of a material or product that is recycled into a new product at the end of its defined life the life of a material or product up to the point of disposal

a type of photovoltaic cell made from a single crystal or a polycrystalline slice of silicon See Corporate Social Responsibility.

in wind energy, for any given instant, the power available in the wind is proportional to the cube of the wind velocity

A network of pipes which carry our drainage system underground

the lowest wind speed at which a wind turbine begins producing usable power

the highest wind speed at which a wind turbine stops producing power

the loss of heat as the water circulates through a water heater tank and inlet and outlet pipes

a furnace or combustion chamber in which finely ground fuel is blown in spirals to maximize combustion efficiency

the number of consecutive days that a stand-alone renewable energy system will meet a defined load without additional energy input

See direct current.

the angular position of the sun at solar noon with respect to the plane of the equator

the process of breaking down organic material

discharging a battery to $20 \%$ or less of its full charge capacity

deposition of raw or treated, filtered hazardous waste by pumping it into deep wells, where it is

contained in the pores of permeable subsurface rock

a unit used to determine the heating requirements of buildings, representing a fall of one degree

below a specified average outdoor temperature (usually $18^{\circ} \mathrm{C}$ ) for one day

the product of 1 hour, and usually the number of degrees the hourly mean temperature is above a base point

a slender threadlike spike of pure crystalline material, such as silicon

the load-carrying ability of an electric power plant during a specific time interval and period when

related to the characteristics of the load to be supplied

the process of removing moisture 


\begin{tabular}{|c|c|}
\hline design tip speed ratio & $\begin{array}{l}\text { The ratio of the speed of the tip of a wind turbine blade for which the power coefficient is at } \\
\text { maximum. See also power coefficient. }\end{array}$ \\
\hline diffuse solar radiation & $\begin{array}{l}\text { sunlight scattered by atmospheric particles and gases so that it arrives at the earth's surface from all } \\
\text { directions and cannot be focused }\end{array}$ \\
\hline digester & $\begin{array}{l}\text { A device in which organic material is biochemically decomposed by anaerobic bacteria to treat the } \\
\text { material and/or to produce biogas. See also anaerobic digestion and biogas. }\end{array}$ \\
\hline diode & an electronic device that allows current to flow in one direction only \\
\hline direct beam radiation & solar radiation that arrives in a straight line from the sun \\
\hline direct current (DC) & $\begin{array}{l}\text { a type of electricity transmission and distribution by which electricity flows in one direction through } \\
\text { the conductor }\end{array}$ \\
\hline direct firing & $\begin{array}{l}\text { Burning bioenergy feedstocks directly to produce heat. The steam drives a turbine, which turns a } \\
\text { generator that converts the power into electricity. }\end{array}$ \\
\hline direct solar water heater & a system that uses water as the fluid that is circulated through the collector to the storage tank \\
\hline direct-firing & $\begin{array}{l}\text { The burning of bioenergy feedstocks directly to produce steam, which is used to produce electricity. } \\
\text { The steam drives a turbine, the turbine turns a generator, and the generator converts the power into } \\
\text { electricity. }\end{array}$ \\
\hline disposal & final placement or destruction of toxic, radioactive or other wastes \\
\hline district heating & $\begin{array}{l}\text { a heating system in which steam or hot water is piped from a central boiler plant to a group of } \\
\text { buildings }\end{array}$ \\
\hline donor & $\begin{array}{l}\text { An } n \text {-type dopant of a solar photovoltaic device that puts an additional electron into an energy level } \\
\text { very near the conduction band. See also dopant. }\end{array}$ \\
\hline dopant & $\begin{array}{l}\text { a chemical element added in small amounts to an otherwise pure semiconductor material to modify } \\
\text { the electrical properties of the material }\end{array}$ \\
\hline doping & The addition of dopants to a semiconductor. See also dopant. \\
\hline downwind wind turbine & a horizontal axis wind turbine in which the rotor is downwind of the tower \\
\hline draft diverter & $\begin{array}{l}\text { a door-like device located at the mouth of a chimney flue for controlling the direction and flow of the } \\
\text { draft as well as the amount of oxygen that the fire receives }\end{array}$ \\
\hline draft hood & $\begin{array}{l}\text { a device built into or installed above a combustion appliance to assure the escape of combustion } \\
\text { byproducts, to prevent backdrafting or to neutralize the effects of the stack action of the chimney on } \\
\text { the operation of the appliance }\end{array}$ \\
\hline drag & $\begin{array}{l}\text { resistance caused by friction in the direction opposite to that of movement of components such as } \\
\text { wind turbine blades }\end{array}$ \\
\hline drainback solar system & $\begin{array}{l}\text { a closed-loop solar heating system in which the heat transfer fluid in the collector loop drains into a } \\
\text { tank or reservoir whenever the booster pump stops to protect the collector loop from freezing }\end{array}$ \\
\hline draindown solar system & $\begin{array}{l}\text { an open-loop solar heating system in which the heat transfer fluid from the collector loop and the } \\
\text { piping drain into a drain whenever freezing conditions occur }\end{array}$ \\
\hline dual fuel vehicle & $\begin{array}{l}\text { A vehicle with an engine capable of operating on two different types of fuels. Also called a flex fuel } \\
\text { vehicle. }\end{array}$ \\
\hline dynamometer & an apparatus for measuring force or power, especially the power developed by a motor \\
\hline ecosystem & $\begin{array}{l}\text { an interconnected and symbiotic grouping of animals, plants, fungi and micro-organisms that sustain } \\
\text { life through biological, geological and chemical activity }\end{array}$ \\
\hline edge-defined film-fed growth (EFG) & $\begin{array}{l}\text { a method for making sheets of polycrystalline silicon for solar photovoltaic devices in which molten } \\
\text { silicon is drawn upward by capillary action through a mould }\end{array}$ \\
\hline EED & the Energy Efficiency Directive of the European Union \\
\hline effective capacity & the maximum load that a device is capable of carrying \\
\hline efficacy & the amount of energy service or useful energy delivered per unit of energy input \\
\hline EFG & See edge-defined film-fed growth. \\
\hline electrical bus & $\begin{array}{l}\text { An electrical conductor that serves as a common connection for two or more electrical circuits. It may } \\
\text { be in the form of rigid bars or stranded conductors or cables. }\end{array}$ \\
\hline electricity grid & an electricity transmission and distribution system \\
\hline electrode & a conductor that is brought in conducting contact with a ground \\
\hline emission & a substance or pollutant emitted as a result of a process \\
\hline emission factor & $\begin{array}{l}\text { a measure of the average amount of a specified pollutant or material emitted for a specific type of } \\
\text { fuel or process }\end{array}$ \\
\hline employability & $\begin{array}{l}\text { a set of achievements - skills, understandings and personal attributes - that make graduates more } \\
\text { likely to gain employment and be successful in their chosen occupations, which benefits themselves, } \\
\text { the workforce, the community and the economy }\end{array}$ \\
\hline EMS & See Energy Management System. \\
\hline energy audit & the process of determining the energy consumption of a building or facility \\
\hline energy crop & crop grown specifically for its fuel value \\
\hline energy density & the ratio of available energy per kilogram \\
\hline energy efficiency class & $\begin{array}{l}\text { In the European Union, the energy efficiency of cars, light bulbs and household appliances is rated in a } \\
\text { set of energy efficiency classes from A to G, A being the most energy efficient. See also EU energy } \\
\text { label. }\end{array}$ \\
\hline energy equipment payback time & the time required for generating energy spent in manufacturing the energy system \\
\hline Energy Management System (EMS) & $\begin{array}{l}\text { A set of elements of plans establishing energy efficiency objectives and strategies to achieve these } \\
\text { objectives. Energy audits are an integral part of energy management systems. See also energy audit. }\end{array}$ \\
\hline energy mix & the distribution or proportion of different energy sources within the total energy supply \\
\hline energy security & $\begin{array}{l}\text { the extent to which a nation's or region's energy supplies are robust against potential disruption, } \\
\text { including factors such as depletion of natural resources, variability and the political stability of regions } \\
\text { where the energy supplies are obtained or trans-shipped }\end{array}$ \\
\hline
\end{tabular}




\begin{tabular}{|c|c|}
\hline EN RD & $\begin{array}{l}\text { is the European Network for Rural Development which aims to regroup national } \\
\text { networks, organizations and administrations active in the field of rural development at } \\
\text { Community level. The network's main aims are to: collect, analyze and disseminate } \\
\text { information on Community rural development measures, collect, disseminate and } \\
\text { consolidate at Community level good rural development practice; provide information } \\
\text { on developments in the Community's rural areas; organize meetings and seminars at } \\
\text { Community level for those actively involved in rural development; set up and run } \\
\text { expert networks with a view to facilitating an exchange of expertise and supporting } \\
\text { implementation and evaluation of the rural development policy; support the national } \\
\text { networks and trans-national cooperation initiatives. }\end{array}$ \\
\hline entrained bed gasifier & a gasifier in which the feedstock is suspended by the movement of gas to move it through the gasifier \\
\hline environment & The land, water and air on or in which people, animals and plants live. \\
\hline environment & all the natural and living things around us, such as the earth, air, plants and animals \\
\hline equalization & the process of restoring all cells in a battery to an equal state-of-charge \\
\hline equinox & the time when the sun crosses the equator, making night and day of equal length all over the earth \\
\hline ETBE & ethyl tertiary butyl ether \\
\hline ethanol & ethyl alcohol $(\mathrm{C} 2 \mathrm{H} 5 \mathrm{OH})$ \\
\hline ethical consumerism & $\begin{array}{l}\text { the purchasing of products that do not harm or exploit the environment and the workers who } \\
\text { produce a product }\end{array}$ \\
\hline EU energy label & $\begin{array}{l}\text { In the European Union, cars, light bulbs and household appliances must have an EU energy label } \\
\text { clearly displayed when they are offered for sale or rent. The EU energy label shows the energy } \\
\text { efficiency class of the product. See also energy efficiency class. }\end{array}$ \\
\hline EU ETS & the Emissions Trading Scheme of the European Union \\
\hline evacuated tube & $\begin{array}{l}\text { in a solar thermal collector, an absorber tube, which is contained in an evacuated glass cylinder, } \\
\text { through which collector fluids flow }\end{array}$ \\
\hline feathering & $\begin{array}{l}\text { In wind generators, the process of adjusting the blades so that they catch less wind. This can prevent } \\
\text { damage to the machine in high winds. }\end{array}$ \\
\hline feedstock & a raw material that can be converted to one or more products \\
\hline fermentation & $\begin{array}{l}\text { the decomposition of organic material to alcohol, methane, etc, by organisms, such as yeast or } \\
\text { bacteria, usually in the absence of oxygen }\end{array}$ \\
\hline fill factor & $\begin{array}{l}\text { the ratio of a photovoltaic cell's actual power to its power if both current and voltage were at their } \\
\text { maxima }\end{array}$ \\
\hline flat plate collector & $\begin{array}{l}\text { a solar thermal collector that converts the sun's radiation into heat on a flat surface without any } \\
\text { reflecting surfaces or lens arrangements to concentrate it }\end{array}$ \\
\hline flat plate solar photovoltaic module & $\begin{array}{l}\text { an arrangement of photovoltaic cells or material mounted on a rigid flat surface with the cells } \\
\text { exposed freely to incoming sunlight }\end{array}$ \\
\hline float-zone process & $\begin{array}{l}\text { In solar photovoltaic cell manufacturing, a method of growing a large-size, high-quality crystal } \\
\text { whereby coils heat a polycrystalline ingot placed on top of a single-crystal seed. As the coils are slowly } \\
\text { raised, the molten interface beneath the coils becomes a single crystal. }\end{array}$ \\
\hline flow condition & $\begin{array}{l}\text { in solar thermal collectors, the condition where the heat transfer fluid is flowing through the collector } \\
\text { loop under normal operation conditions }\end{array}$ \\
\hline flue & $\begin{array}{l}\text { the structure into which combustion gases flow and are contained until they are emitted to the } \\
\text { atmosphere }\end{array}$ \\
\hline fossil fuels & $\begin{array}{l}\text { fuels formed in the ground from the remains of dead plants and animals, such as oil, natural gas and } \\
\text { coal }\end{array}$ \\
\hline freestanding tower & An expensive type of wind generator tower with no guy wires. See also guy wires. \\
\hline fuel cell & an electrochemical device that converts chemical energy directly into electricity \\
\hline fuel efficiency & the ratio of heat produced by a fuel for doing work to the available heat in the fuel \\
\hline fuel oil & any liquid petroleum product burned for the generation of heat or power \\
\hline fuel rate & the amount of fuel necessary to generate one kilowatt-hour of electricity \\
\hline fuel wood & wood and wood products that are used by direct combustion \\
\hline fuel wood & any material that can be burned to make energy \\
\hline full sun & $\begin{array}{l}\text { the amount of power density in sunlight received at the earth's surface at noon on a clear day (about } \\
1,000 \text { Watts/square metre) }\end{array}$ \\
\hline fungi & $\begin{array}{l}\text { Organisms with cells with distinct nuclei surrounded by nuclear membranes, incapable of } \\
\text { photosynthesis. They are able to decompose waste organisms and exist as yeast, mold or mildew. }\end{array}$ \\
\hline furling & $\begin{array}{l}\text { the process of forcing, either manually or automatically, a wind turbine's blades out of the direction } \\
\text { of the wind in order to stop the blades from turning }\end{array}$ \\
\hline furnace & a combustion heating appliance in which heat is captured from the burning of a fuel for distribution \\
\hline gallium arsenide & a compound used to make certain types of solar photovoltaic cells \\
\hline gas turbine & $\begin{array}{l}\text { a type of turbine in which combusted, pressurized gas is directed against a series of blades connected } \\
\text { to a shaft, which forces the shaft to turn to produce mechanical energy }\end{array}$ \\
\hline gasification & $\begin{array}{l}\text { The process in which a solid fuel is converted into a gas. Also known as pyrolitic distillation or } \\
\text { pyrolysis. }\end{array}$ \\
\hline gasifier & a device for converting a solid fuel into a gaseous fuel \\
\hline generator & a device that converts mechanical energy into electrical energy \\
\hline generating station & see wind power plant \\
\hline geothermal energy & thermal energy generated and stored in the Earth \\
\hline geothermal plant & $\begin{array}{l}\text { a plant where the prime mover is a steam turbine driven by steam produced from hot water or by } \\
\text { natural steam that derives its energy from heat found in rock }\end{array}$ \\
\hline gigawatt (GW) & a unit of power equal to 1 billion Watts, 1 million kilowatts, or 1 thousand megawatts \\
\hline gin pole & a device that is used with wind generator towers with a tilt-up tower \\
\hline global warming & a term used to describe the Earth's gradual warming due to the greenhouse effect \\
\hline
\end{tabular}




\begin{tabular}{|c|c|}
\hline glycol & an antifreeze and heat transfer fluid circulated through closed loop solar hot water collectors \\
\hline good practice & $\begin{array}{l}\text { examples of successful projects (or initiatives), intended to show the practical achievements of the } \\
\text { objectives of rural development programmes }\end{array}$ \\
\hline governing & the action limiting the output of a device \\
\hline governor & a device limiting the output of another device, such as a wind generator \\
\hline grain alcohol & ethanol (ethyl alcohol) \\
\hline green economy & $\begin{array}{l}\text { an economy that results in improved human well-being and social equity, while aiming at reducing } \\
\text { environmental risks and ecological scarcities }\end{array}$ \\
\hline green growth & $\begin{array}{l}\text { a term describing a path of economic growth that uses natural resources in a sustainable manner, also } \\
\text { fostering economic growth and development while ensuring that natural assets continue to provide } \\
\text { the resources and environmental services }\end{array}$ \\
\hline green power & see clean power \\
\hline green supply chain & $\begin{array}{l}\text { the management of purchasing decisions in order to consider sustainable impacts of raw materials } \\
\text { acquisition, production, manufacturing, packaging, distribution, reuse, operation, maintenance or } \\
\text { disposal }\end{array}$ \\
\hline greenhouse effect & $\begin{array}{l}\text { the process during which rise in temperature is experiencedas certain gases in the atmosphere trap } \\
\text { energy from the sun }\end{array}$ \\
\hline greenhouse gases & $\begin{array}{l}\text { gases in the Earth's atmosphere producing greenhouse effect, including carbon dioxide, methane, } \\
\text { nitrous oxide, etc. }\end{array}$ \\
\hline greenspace & $\begin{array}{l}\text { a piece of land intentionally undeveloped for the purpose of preservation or conservation of a } \\
\text { community or region's natural or historic character, or for the sake of recreational, ecological, } \\
\text { aesthetic or agricultural interests }\end{array}$ \\
\hline greenwash & $\begin{array}{l}\text { disinformation disseminated by an organisation in order to present an environmentally responsible } \\
\text { public image }\end{array}$ \\
\hline greenwood & freshly cut wood \\
\hline greywater & $\begin{array}{l}\text { all wastewater generated in households or office buildings from streams without fecal contamination, } \\
\text { and it is used for landscape irrigation depending on the source of greywater; also called sullage }\end{array}$ \\
\hline grid lines & $\begin{array}{l}\text { metallic contacts fused to the surface of a solar cell in order to provide a low resistance path for } \\
\text { electrons to flow out to the cell interconnect wires }\end{array}$ \\
\hline grid-connected system & $\begin{array}{l}\text { an independent power system connected to an electricity transmission and distribution system in a } \\
\text { way that the system can draw on the grid's reserve capacity when needed, and feed electricity back } \\
\text { into the grid during times of excess production }\end{array}$ \\
\hline grid-tie system & a renewable energy system connected to the utility grid, selling excess energy back to the utility \\
\hline gross generation & $\begin{array}{l}\text { the total amount of electric energy produced by the generating units of a generating station, } \\
\text { measured at the generator terminals }\end{array}$ \\
\hline ground mount & a photovoltaic rack that is designed to be installed on the ground or on other flat surface \\
\hline ground reflection & solar radiation that is reflected from the ground onto a solar collector \\
\hline guy wires & steel cables supporting a tower \\
\hline habitat & an ecological or environmental area that is the natural home of animals, plants or a communities \\
\hline heat gain & $\begin{array}{l}\text { the amount of heat entering to a space from all heat producing sources, such as building occupants, } \\
\text { lights, appliances, and from the environment, mainly solar energy }\end{array}$ \\
\hline heat loss & $\begin{array}{l}\text { the amount of heat flowing from the building interior, through the building envelope to the outer } \\
\text { environment, see also building envelope }\end{array}$ \\
\hline heat rate & $\begin{array}{l}\text { the ratio of fuel energy input as heat per unit of net work output, which is also a measure of a power } \\
\text { plant thermal efficiency }\end{array}$ \\
\hline heat storage & a device or media absorbing heat for storage for later use \\
\hline heat storage capacity & the amount of heat that can be absorbed and stored by a material \\
\hline heat transfer & $\begin{array}{l}\text { the exchange of thermal energy between physical systems, depending on the temperature and } \\
\text { pressure, also on the flow of heat from one area to another by conduction, convection, and/or } \\
\text { radiation }\end{array}$ \\
\hline heat transmission coefficient & $\begin{array}{l}\text { any coefficient that is used to calculate heat transmission by conduction, convection or radiation } \\
\text { through materials or structures }\end{array}$ \\
\hline heating capacity & $\begin{array}{l}\text { the quantity of heat needed to raise the temperature of a specific mass of substance by one degree, } \\
\text { also called specific heat }\end{array}$ \\
\hline heating fuel & any gaseous, liquid or solid fuel that is used for indoor space heating \\
\hline heating fuel unit & standardized weight or volume for heating fuels \\
\hline heating load & $\begin{array}{l}\text { the quantity of heat per unit time that must be supplied to maintain a specific indoor temperature in } \\
\text { a building or portion of a building }\end{array}$ \\
\hline heating seasonal performance factor (HSPF) & $\begin{array}{l}\text { a term specifically used to measure the efficiency of air source heat pumps operating in the heating } \\
\text { mode }\end{array}$ \\
\hline heliochemical process & the utilization of solar energy through photosynthesis \\
\hline heliodon & $\begin{array}{l}\text { a device that is used to simulate the angle of the sun for assessing shading potentials of building } \\
\text { structures or landscape features }\end{array}$ \\
\hline heliostat & a device including a turning mirror in order to keep reflecting sunlight toward a predetermined target \\
\hline heliostat & a device tracking the movement of the sun and used to orient solar concentrating systems \\
\hline heliothermal & any process using solar radiation to produce useful heat \\
\hline heliothermic site planning & $\begin{array}{l}\text { site planning that explains natural solar heating and cooling processes and their relationship to } \\
\text { building shape, orientation and siting }\end{array}$ \\
\hline heliothermometer & an instrument for the purpose of measuring the intensity solar radiation \\
\hline heliotropic & $\begin{array}{l}\text { any device or plant turning or growing towards the sunlight, following the sun's apparent movement } \\
\text { across the sky }\end{array}$ \\
\hline hemispherical bowl technology & $\begin{array}{l}\text { a solar energy concentrating technology using a linear receiver that tracks the focal area of a reflector } \\
\text { or array of reflectors }\end{array}$ \\
\hline
\end{tabular}




\begin{tabular}{|c|c|}
\hline Hertz & the frequency with which an alternating current waveform rises and falls while it changes polarity \\
\hline high-temperature collector & a type of solar thermal collector designed to operate at a minimum temperature of 80 degrees Celsius \\
\hline homojunction & $\begin{array}{l}\text { a semiconductor interface occuring between layers (n-layer and p-layer) of similar semiconductor } \\
\text { material in photovoltaic cells }\end{array}$ \\
\hline horizontal-axis wind turbine & $\begin{array}{l}\text { a type of wind turbine where the axis of the rotor's rotation is parallel to both the wind stream and } \\
\text { the ground }\end{array}$ \\
\hline HSPF & see heating seasonal performance factor \\
\hline hub & the centre of a wind generator rotor holding the blades in place and connects to the shaft \\
\hline hub height & $\begin{array}{l}\text { the distance between the turbine platform and the rotor of an installed wind turbine, indicating how } \\
\text { high the turbine stands above the ground }\end{array}$ \\
\hline humidifier & a device that is used to increase a specified humidity in a conditioned space \\
\hline humidity & the amount of water vapor in the air, also a measure of the moisture content in the air \\
\hline hybrid system & $\begin{array}{l}\text { a dynamic renewable energy system including two different types of technologies that produce the } \\
\text { same type of energy, exhibiting both continuous and discrete dynamic behavior }\end{array}$ \\
\hline hydropower & $\begin{array}{l}\text { power derived from the energy of falling water or fast running water, which may be restrained for } \\
\text { useful purposes }\end{array}$ \\
\hline hydropower storage & $\begin{array}{l}\text { a hydropower facility storing water in a reservoir during high-inflow periods to supplement water } \\
\text { during low-inflow period while allowing the flow to release and making power production more } \\
\text { flexible and dependable }\end{array}$ \\
\hline ignite & to inflame a gaseous mixture to the temperature at which combustion will occur \\
\hline ignition point & the minimum temperature at which combustion of a solid or fluid may happen \\
\hline impoundment & a water reservoir confined by a dam, dike, floodgate or other artificial barrier \\
\hline impulse turbine & $\begin{array}{l}\text { a type of turbine driven by high velocity jets of water or steam from a nozzle directed to vanes or } \\
\text { buckets attached to a wheel, and they also change the direction of flow of a high velocity fluid or gas } \\
\text { jet }\end{array}$ \\
\hline incident solar radiation & the amount of solar radiation energy collected on a given surface during a given time \\
\hline independent power producer & $\begin{array}{l}\text { a company or individual that is not a regulated power provider, producing power for their own use } \\
\text { and/or sell it to regulated power providers }\end{array}$ \\
\hline indirect solar gain system & $\begin{array}{l}\text { a passive solar heating system where the sun warms up a heat storage element, and the heat is } \\
\text { distributed to the interior space by convection, conduction and radiation }\end{array}$ \\
\hline indirect solar water heater & $\begin{array}{l}\text { these types of systems circulate fluids other than water through the collector using a heat exchanger } \\
\text { that separates the potable water from the fluid, known as the "heat-transfer fluid" (HTF) that } \\
\text { circulates through the collector; also called closed loop systems }\end{array}$ \\
\hline industrial process heat & the thermal energy used during an industrial process \\
\hline infrared radiaton & $\begin{array}{l}\text { electromagnetic radiation with longer wavelengths; invisible long wavelength radiation (heat) is } \\
\text { capable of producing a thermal or photovoltaic effect }\end{array}$ \\
\hline input power & the power used by a device to produce useful work expressed in Watts, also called active power \\
\hline insolation & $\begin{array}{l}\text { the solar radiation reaching the Earth's surface affecting temperature, the more the isolation the } \\
\text { higher the temperature is }\end{array}$ \\
\hline instantaneous efficiency (of a solar collector) & $\begin{array}{l}\text { the amount of energy captured (or converted) by a solar collector (or photovoltaic cell or module) } \\
\text { during a } 15 \text { minute period }\end{array}$ \\
\hline integral collector storage system & $\begin{array}{l}\text { a simple passive solar hot water system consisting of one or more storage tanks placed in an insulated } \\
\text { box with a glazed side facing the sun; also known as bread box systems or batch heaters }\end{array}$ \\
\hline integrated heating system & $\begin{array}{l}\text { a type of heating appliance performing more than one function, for example space and water heating } \\
\text { and they work with several types of appliances such as boilers, ground source heat pumps or solar } \\
\text { thermal systems }\end{array}$ \\
\hline integrated resource plan (IRP) & $\begin{array}{l}\text { a plan developed by an electric power provider, sometimes as required by a public regulatory } \\
\text { commission or agency, defying the short and long term capacity additions (supply side) and demand } \\
\text { side management programs that it will meet projected energy demands }\end{array}$ \\
\hline intermittent generators & $\begin{array}{l}\text { power plants in which output depends on a factor(s) which cannot be controlled by the power } \\
\text { generator as the result of the utilization of intermittent resources such as solar energy or wind }\end{array}$ \\
\hline internal combustion electric power plant & $\begin{array}{l}\text { the generation of electric power by a heat engine which is able to convert part of the heat generated } \\
\text { by combustion of the fuel into mechanical motion in order to operate an electric generator }\end{array}$ \\
\hline intrinsic layer & $\begin{array}{l}\text { a layer of semiconductor material (as used in a solar photovoltaic device) whose properties are } \\
\text { essentially equal to the pure material }\end{array}$ \\
\hline inverter & $\begin{array}{l}\text { an electronic device converting direct current electricity to alternating current for the purpose of } \\
\text { using it directly to operate appliances or to supply power to a electricity grid }\end{array}$ \\
\hline irradiance & the radiant flux (direct, diffuse and reflected solar radiation) received by a surface per unit area \\
\hline isolated solar gain system & $\begin{array}{l}\text { a type of passive solar heating system in which heat is collected in one area for further use in another } \\
\text { area }\end{array}$ \\
\hline I-V curve & $\begin{array}{l}\text { a currect voltage curve representing the current and voltage output of a solar photovoltaic cell or } \\
\text { module, as the capacity of the device is increased from short circuit condition to open circuit } \\
\text { condition }\end{array}$ \\
\hline Joule & $\begin{array}{l}\text { a derived metric unit of energy or work, also the amount of energy produced by a force of one } \\
\text { Newton operating through a distance of one meter }\end{array}$ \\
\hline Joule's law & $\begin{array}{l}\text { firstly the rate of heat production by a steady current in any part of an electrical circuit proportional } \\
\text { to the resistance and to the square of the current, and secondly stating that the internal energy of an } \\
\text { ideal gas depends only on its temperature }\end{array}$ \\
\hline Kaplan turbine & $\begin{array}{l}\text { a type of turbine with two blades whose pitch is adjustable and it may have gates to control the angle } \\
\text { of the fluid flow into the blades }\end{array}$ \\
\hline
\end{tabular}




\begin{tabular}{|c|c|}
\hline landfill & a site for disposing waste, where solid waste is buried between layers of soil \\
\hline landfill gas & $\begin{array}{l}\text { a complex mix of different gases generated by decomposition of organic materials at landfill waste } \\
\text { disposal sites }\end{array}$ \\
\hline landscaping & $\begin{array}{l}\text { any activity modifying the visible features and vegetation of an area for aesthetics and energy } \\
\text { conservation purposes }\end{array}$ \\
\hline Langley & a unit of energy distribution over an area, also a measure of solar radiation \\
\hline law(s) of thermodynamics & $\begin{array}{l}\text { the first law stating that energy can not be created or destroyed; the second law stating that if a free } \\
\text { exchange of heat occurs between two materials, the heat always moves from the warmer towards the } \\
\text { cooler material }\end{array}$ \\
\hline leading edge & $\begin{array}{l}\text { in a wind energy conversion system, the foremost part of a turbine blade surface that first contacts } \\
\text { the wind }\end{array}$ \\
\hline lethe & a measure of air purity equal to one complete air change in an interior space \\
\hline lift & the force pulling a wind turbine blade, as opposed to dragging it \\
\hline light trapping & $\begin{array}{l}\text { the trapping of light inside a semiconductor material by refracting and reflecting the light at different } \\
\text { angles; trapped light will travel further in the material, notably increasing the probability of } \\
\text { absorption and thus of producing charge carriers }\end{array}$ \\
\hline liquid-based solar heating system & a solar heating system using a liquid as the heat transfer fluid \\
\hline liquid-to-air heat exchanger & a heat exchanger device transferring heat contained in a liquid heat transfer fluid to air \\
\hline liquid-to-liquid heat exchanger & a heat exchanger device transferring heat contained in a liquid heat transfer fluid to another liquid \\
\hline local & $\begin{array}{l}\text { the immediate area around the site of business operations and it might vary depending on the density } \\
\text { of the location }\end{array}$ \\
\hline local community & $\begin{array}{l}\text { a group of interacting people living in the neighbouring area potentially affected socially, } \\
\text { economically and/or environmentally }\end{array}$ \\
\hline local development strategy (LDS) & $\begin{array}{l}\text { a spatial planning strategy prepared and implemented by the LAG for a given area } \\
\text { keeping in mind to achieve the objectives of one or more of the three thematic rural } \\
\text { development axes in order to contribute to local development }\end{array}$ \\
\hline local solar time & $\begin{array}{l}\text { apparent solar time (sundial time) which is used in a system of astronomical time where the sun } \\
\text { crosses the true north-south meridian at } 12 \text { noon, and it is different from local time according to } \\
\text { longitude, time zone, and equation of time }\end{array}$ \\
\hline log law & $\begin{array}{l}\text { logarithmic law with reference to a wind energy conversion system, in which wind speeds increase } \\
\text { with the logarithmic of the height of the wind turbine above the ground }\end{array}$ \\
\hline loose fill insulation & $\begin{array}{l}\text { insulation made from rockwool fibers, fiberglass, cellulose fiber, vermiculite or perlite minerals, and } \\
\text { they are composed of loose fibers or granules that can be applied by pouring them directly from a bag } \\
\text { or with a blower }\end{array}$ \\
\hline loss of load probability (LOLP) & $\begin{array}{l}\text { an estimated number, also the measure of the probability that a system demand will exceed capacity } \\
\text { during a given period of time }\end{array}$ \\
\hline low-e coatings and (window) films & $\begin{array}{l}\text { a coating applied to the surface of the window glazing in order to reduce heat transfer through the } \\
\text { window }\end{array}$ \\
\hline low-emissivity windows and (window) films & $\begin{array}{l}\text { energy-efficient windows with a coating or film applied to the surface of the glass in order to reduce } \\
\text { heat transfer through the window }\end{array}$ \\
\hline low-flow solar water heating systems & $\begin{array}{l}\text { the flow rate in these systems ranges from } 1 / 8 \text { to } 1 / 5 \text { the rate of solar water heating systems in } \\
\text { general, taking advantage of stratification in the storage tank and theoretically allowing the use of } \\
\text { smaller diameter piping to and from the collector and a smaller pump }\end{array}$ \\
\hline lumen & $\begin{array}{l}\text { an empirical measure of the quantity of light based upon the spectral sensitivity of the photosensors } \\
\text { in the human eye under high (daytime) light levels }\end{array}$ \\
\hline luminance & $\begin{array}{l}\text { a photometric measure of the luminous intensity per unit area of light travelling in a given direction, } \\
\text { also the subjective sensation of brightness measured in lumens }\end{array}$ \\
\hline lux & $\begin{array}{l}\text { the SI unit of illuminance equivalent to } 1 \text { lumen per square meter, measuring luminous flux per unit } \\
\text { area }\end{array}$ \\
\hline magnetic ballast & a type of florescent light ballast using a magnetic core to regulate the voltage of a florescent lamp \\
\hline mass burn facility & $\begin{array}{l}\text { a type of municipal solid waste (MSW) incineration facility in which MSW is burned with only minor } \\
\text { presorting to remove oversize, hazardous or explosive materials; its major components include refuse } \\
\text { receiving and handling, combustion and steam generation, flue gas cleaning, power generation, } \\
\text { condenser cooling water, residue ash hauling and landfilling }\end{array}$ \\
\hline mean power output & the average power output of a wind energy conversion system at a given mean wind speed \\
\hline mean wind speed & the arithmetic wind speed over a particular time period and height above the ground \\
\hline median wind speed & the speed of wind with 50 percent probability of occurring \\
\hline metric ton & a unit of mass equal to 1000 kilograms \\
\hline microclimate & $\begin{array}{l}\text { a local climate or atmospheric zone of specific place or habitat, and its climate is different from the } \\
\text { surrounding area }\end{array}$ \\
\hline microgroove & a small groove scraped into the surface of a solar photovoltaic cell that is filled with metal for contacts \\
\hline mixing valve & $\begin{array}{l}\text { a valve operated by a thermostat installed in solar water heating systems to mix cold water with } \\
\text { water from the collector loop in order to provide a safe water temperature }\end{array}$ \\
\hline module & $\begin{array}{l}\text { the smallest self-sufficient, environmentally protected structure containing interconnected } \\
\text { photovoltaic cells and providing a single dc electrical output; also called a panel }\end{array}$ \\
\hline monoculture & $\begin{array}{l}\text { a type of agricultural practice, the planting, cultivation, and harvesting of a single species of crop or } \\
\text { plant in a specified area or farming system }\end{array}$ \\
\hline multijunction device (MJ device) & $\begin{array}{l}\text { a high-efficiency photovoltaic device containing multiple cell junctions made of different } \\
\text { semiconductor materials, each of them is optimized for a particular part of the solar spectrum }\end{array}$ \\
\hline municipal solid waste (MSW) & $\begin{array}{l}\text { a type of waste material consisting of everyday items (not hazardous) discarded by the public } \\
\text { (households and businesses) in a community }\end{array}$ \\
\hline
\end{tabular}


municipal waste to energy project (or plant) a facility producing fuel or energy from municipal solid waste

nacelle

a cover housing for the gear box, drive train, generator, and other generating components of a wind turbine

space cooling obtained by shading, natural ventilation, conduction control, radiation, and evaporation; also called passive cooling

\begin{tabular}{l}
\hline net energy production (or balance) \\
\hline net generation \\
\hline nominal capacity \\
\hline non-renewable fuels \\
non-utility generator/power producer \\
\hline \\
ocean energy systems \\
\hline one sun
\end{tabular}

the amount of useful energy produced by a system less the amount of energy required to produce the fuel

gross generation less the electric energy consumed at the generating station for station's use the approximate energy producing capacity of a power plant under special conditions

fuels that cannot be easily made or "renewed," such as oil, natural gas, and coal

a class of power generator with generating plants for the purpose of supplying electric power

required in the conduct of their industrial and commercial operations

energy conversion technologies harnessing the energy in tides, waves, and thermal gradients in the oceans

\begin{tabular}{|l|l}
\hline one sun & the \\
\hline
\end{tabular}

open-circuit voltage (OCV) the maximum value of natural solar insolation

the difference of electrical potential between two terminals of a device when disconnected from any circuit, also the maximum possible voltage across a photovoltaic cell

these types of "direct" systems circulate water drawn from a ground or surface water source; once

open loop geothermal heat pump system

the heat has been transferred into or out of the water, the water is returned to a well or surface discharge

orientation

in architecture, the alignment of a building along a given axis to face a specific geographical direction

outgassing

the process by which materials expel or release gasses

a building element providing shade to windows, walls, and doors from direct solar radiation and

overhang protects these elements from precipitation

ovonic

a device converting heat or sunlight directly to electricity, having a unique glass composition that changes from an electrically non-conducting state to a semiconducting state

gasoline fuel additives such as ethanol, ETBE, or MTBE that add extra oxygen to gasoline to reduce carbon monoxide pollution produced by vehicles

oxygenates

packing factor

the ratio of solar collector array area to actual land area

panel (solar)

panel radiator

panemone

or modules

a mainly flat surface for transmitting radiant energy

a drag-type wind machine that is able to react to wind from any direction

a solar energy conversion device with a bowl shaped dish covered with a highly reflective surface that

can track the sun and concentrates sunlight on a fixed absorber, thereby achieving high temperatures

parabolic dish

for process heating or to produce power or electricity

parabolic trough

a solar energy conversion device using a trough covered with a highly reflective surface to focus sunlight onto a linear absorber that contains a working fluid which can be used for medium temperature space or process heat or to operate a steam turbine for power or electricity generation

parallel connection

a way of joining photovoltaic cells or modules by the means of connecting positive and negative leads together; such a configuration increases the current, but not the voltage

passivation

a chemical reaction eliminating the detrimental effect of electrically reactive atoms on a photovoltaic cell's surface

a building design using structural elements of a building to heat and cool a building without the use of

mechanical equipment, which requires careful consideration of the local climate and solar energy resource, building orientation, and landscape features

passive solar (building) design

a solar water or space-heating system in which solar energy is collected, and/or moved by natural

passive solar heater

passive solar home

convection without using any pumps or fans

a building/house built using passive solar design techniques

payback period

the amount of time over which the energy savings of a project equal the amount of energy expended since project inception; the return to the investment consists of reduced operating cost

a hydropower plant operated at maximum allowable capacity for part of the day and is either shut down for the remaining time period or operated at minimal capacity level

peaking hydropower the equivalent number of hours per day when solar irradiance averages $1 \mathrm{~kW} / \mathrm{m}^{2}$

peak sun hours

a measuring unit used to rate the performance of solar photovoltaic (PV) cells, modules or arrays

peak watt

the maximum instantaneous wind speed (or velocity) occuring within a specific period of time or interval

peak wind speed

pellets

solid fuels primarily made out of wood sawdust that is compacted under high pressure to form small pellets for the purpose of using them in a pellet stove

pellet stove a space heating device burning pellets, and therefore being more efficient, clean burning and easier to operate as opposed to conventional cord wood burning appliances

pelton turbine

a type of impulse hydropower turbine suitable for power extraction, where generally the water energy is available at high head and low flow rate

solar collector thermal performance ratings are based on collector efficiencies, usually expressed in

BTU per hour for solar collectors under standard test or operating conditions for solar radiation

intensity, inlet working fluid temperatures, and ambient temperatures 


\begin{tabular}{|c|c|}
\hline photobiological hydrogen production & $\begin{array}{l}\text { a hydrogen production process using algae, as the pigments in certain types of algae absorb solar } \\
\text { energy and an enzyme in the cell acts as a catalyst to split water molecules }\end{array}$ \\
\hline photovoltaic (conversion) efficiency & the ratio of the electrical output of a solar cell to the incident energy in the form of sunlight \\
\hline photovoltaic (PV; solar) array & a group of solar photovoltaic modules connected together \\
\hline photovoltaic (solar) cell & treated semiconductor material converting solar irradiance into electricity \\
\hline photovoltaic device & $\begin{array}{l}\text { a solid-state electrical device converting light directly into direct current electricity of voltage-current } \\
\text { characteristics; solar photovoltaic devices are made out of various semi-conductor materials including } \\
\text { silicon, cadmium sulfide, cadmium telluride, and gallium arsenide, and in single crystalline, multi- } \\
\text { crystalline, or amorphous forms }\end{array}$ \\
\hline photovoltaic (solar) module or panel & $\begin{array}{l}\text { a solar photovoltaic product, generally consisting of groups of PV cells electrically connected together } \\
\text { to produce a specified power output under standard test conditions, mounted on a substrate, sealed } \\
\text { with an encapsulant and covered with a protective glazing }\end{array}$ \\
\hline photovoltaic (solar) system & $\begin{array}{l}\text { a complex PV power system consisting of the module (or array) and balance-of-system (BOS) } \\
\text { components including the array supports, electrical conductors/wiring, fuses, safety disconnects, and } \\
\text { grounds, charge controllers, inverters, battery storage, etc. }\end{array}$ \\
\hline physical vapor deposition & $\begin{array}{l}\text { a method of depositing thin semiconductor (photovoltaic) films, during which method physical } \\
\text { processes are used to deposit elemental semiconductor material on a substrate }\end{array}$ \\
\hline pitch control & $\begin{array}{l}\text { a method of controlling a wind turbine's speed by changing the orientation or pitch of the blades, and } \\
\text { therefore adjusting its aerodynamics and efficiency }\end{array}$ \\
\hline P-I-N & $\begin{array}{l}\text { a semiconductor (photovoltaic) device structure overlaying a basic semiconductor between a p-type } \\
\text { semiconductor and an n-type semiconductor }\end{array}$ \\
\hline pollution & $\begin{array}{l}\text { an activity during which contaminants are introduced into the natural environment (air, water, land) } \\
\text { causing adverse change and pollutants are generated }\end{array}$ \\
\hline pollution management plan & $\begin{array}{l}\text { a detailed methodology on how to handle and reduce the amount of intoxicating substances or noises } \\
\text { produced by tourism business }\end{array}$ \\
\hline polycrystalline photovoltaic cell & a photovoltaic cell made out of cast-silicon wafers and ribbon-silicon sheets \\
\hline portfolio standard & $\begin{array}{l}\text { a regulation stating the specific percentage of the power generated or purchased by a power } \\
\text { provider, guaranteeing a market for electricity generated from renewable energy resources }\end{array}$ \\
\hline power coefficient & $\begin{array}{l}\text { the ratio showing how efficiently a wind energy convertion device converts wind energy into } \\
\text { electricity }\end{array}$ \\
\hline power (output) curve & it shows a wind energy conversion device's power output versus wind speed \\
\hline power generation mix & $\begin{array}{l}\text { the proportion of electricity distributed by a power provider and is generated from various sources } \\
\text { such as coal, natural gas, petroleum, nuclear, hydropower, wind, or geothermal energy }\end{array}$ \\
\hline power (solar) tower & a type of solar furnice that uses a tower to receive the focused sunlight \\
\hline preheater (solar) & $\begin{array}{l}\text { a solar heating system preheating water or air which is later heated again by another heating } \\
\text { appliance }\end{array}$ \\
\hline process heat & thermal energy used mainly in agricultural and industrial operations where supplying heat is needed \\
\hline projected area & $\begin{array}{l}\text { it is a two-dimensional area measurement of a three-dimensional object, and it is also a solid area } \\
\text { covered at any instant by a wind turbine's blades from the perspective of the direction of the } \\
\text { windstream }\end{array}$ \\
\hline propeller (hydro) turbine & $\begin{array}{l}\text { a turbine having a runner with attached blades similar to a propeller that is used to drive a ship, and } \\
\text { as water passes over the curved propeller blades, it results in the rotation of the shaft }\end{array}$ \\
\hline pumped storage facility & $\begin{array}{l}\text { a type of power generating facility pumping water to a storage reservoir during off-peak periods, and } \\
\text { then using the stored water (by allowing it to fall through a hydro turbine) to generate power during } \\
\text { peak periods }\end{array}$ \\
\hline PV & see photovoltaic \\
\hline pyrolysis & $\begin{array}{l}\text { a type of thermolysis and transformation process of a compound or material into one or more } \\
\text { substances by heat alone (without oxidation) and it is often called destructive distillation; pyrolysis } \\
\text { products genelrally consist of gases, liquids, and char }\end{array}$ \\
\hline rankine cycle & $\begin{array}{l}\text { a thermodynamic cycle being an ideal standard for correlating performance of heat-engines, steam } \\
\text { power plants, steam turbines, and heat pump systems using a condensable vapor as the working fluid }\end{array}$ \\
\hline recirculation systems & $\begin{array}{l}\text { a type of solar heating system (apparently not so efficient) circulating warm water from storage } \\
\text { through the collectors and exposed piping whenever freezing conditions occur }\end{array}$ \\
\hline receiver & $\begin{array}{l}\text { the component part of a central receiver solar thermal system where reflected solar energy is } \\
\text { absorbed and converted into thermal energy }\end{array}$ \\
\hline recycling & the process of converting waste materials into a new (reusable) product \\
\hline refuse-derived fuel (RDF) & $\begin{array}{l}\text { a solid fuel produced by shredding or dehydrating municipal solid waste (MSW) with a waste } \\
\text { converter technology }\end{array}$ \\
\hline renewable energy & $\begin{array}{l}\text { energy derived from resources that are regenerative or for all practical purposes can not be depleted. } \\
\text { Types of renewable energy resources include moving water (hydro, tidal and wave power), thermal } \\
\text { gradients in ocean water, biomass, geothermal energy, solar energy, and wind energy. Municipal solid } \\
\text { waste (MSW) is also considered to be a renewable energy resource }\end{array}$ \\
\hline renewable portfolio standard (RPS) & $\begin{array}{l}\text { a regulation requiring the increased production of energy from renewable energy sources, such } \\
\text { as wind, solar, biomass, and geothermal energy }\end{array}$ \\
\hline resource recovery & $\begin{array}{l}\text { the process of converting municipal solid waste into energy and/or the recovery process of materials } \\
\text { for recycling purposes }\end{array}$ \\
\hline responsible consumption & $\begin{array}{l}\text { a joint effort to purchase and use goods and services with low environmental footprints and provide a } \\
\text { positive economic impact where it is achievable }\end{array}$ \\
\hline reverse thermosiphon flow & $\begin{array}{l}\text { in this case heat seeks to flow from a warm area (e.g., heated space) to a cooler area, such as a solar } \\
\text { air collector at night lacking a reverse flow damper }\end{array}$ \\
\hline ribbon (photovoltaic) cells & $\begin{array}{l}\text { a type of solar photovoltaic device made in a continuous process of pulling material from a molten } \\
\text { bath of photovoltaic material in order to form a thin sheet of material }\end{array}$ \\
\hline
\end{tabular}




\begin{tabular}{|c|c|}
\hline rock bin & $\begin{array}{l}\text { a container filled with rocks to be used as the thermal mass to store solar energy in a solar heating } \\
\text { system }\end{array}$ \\
\hline roof pond & $\begin{array}{l}\text { a solar energy collection device consisting of containers of water located on the top of a roof in order } \\
\text { to absorb solar energy during the day so that the heat collected can be used at night or for passive } \\
\text { cooling purposes }\end{array}$ \\
\hline run-of-river hydropower & $\begin{array}{l}\text { a type of hydroelectric facility using the flow of the river with very little transformation, and little or } \\
\text { no impoundment of the water }\end{array}$ \\
\hline rural development & $\begin{array}{l}\text { a process of improving the quality of life and economic well-being of people living in practically } \\
\text { isolated or with low population density areas }\end{array}$ \\
\hline salt gradient solar ponds & $\begin{array}{l}\text { a solar pond with three main layers: the top layer is near ambient and has low salt content, the } \\
\text { bottom layer is hot and is very salty and the important gradient zone (acting as a transparent } \\
\text { insulator) separates these two zones }\end{array}$ \\
\hline seasoned wood & air dried wood that is used for fuel \\
\hline selective absorber & $\begin{array}{l}\text { a solar absorber surface with high absorbence at wavelengths, corresponding to that of the solar } \\
\text { spectrum and low emittance in the infrared range }\end{array}$ \\
\hline selective surface coating & $\begin{array}{l}\text { a material with high absorbence and low emittance properties applied to or on solar absorber } \\
\text { surfaces }\end{array}$ \\
\hline series connection & a way of joining photovoltaic cells by connecting together positive leads to negative leads \\
\hline sewage & $\begin{array}{l}\text { municipal wastewater from domestic or industrial establishments conveyed in sewers or pipes and } \\
\text { treated at a wastewater treatment plant }\end{array}$ \\
\hline shaft & the part of a turbine spinned by the blades and connected to the generator through a gearbox \\
\hline single-crystal material & $\begin{array}{l}\text { a material that is composed of a single crystal or a few large crystals usually in solar photovoltaic } \\
\text { devices }\end{array}$ \\
\hline sizing & $\begin{array}{l}\text { the process of designing a solar system in order to meet a specified load, given the solar resource and } \\
\text { the nominal or rated energy output of the solar energy collection or conversion device }\end{array}$ \\
\hline smart window & $\begin{array}{l}\text { a general term used to describe a technologically advanced window system containing glazing that } \\
\text { can change or switch its optical qualities when a low voltage electrical signal is applied to it, or in } \\
\text { response to changes in heat or light }\end{array}$ \\
\hline social impact assessment (SIA) & $\begin{array}{l}\text { a methodology to review the social effects of infrastructure projects and other development } \\
\text { interventions, and also the process of analysing, monitoring, and managing the intended and } \\
\text { unintended social consquences, or planned interventions (policies, programs, plans, projected) and } \\
\text { any social change processes appealed to those interventions with the primary purpose of maintaining } \\
\text { a more sustainable and equitable biophysical and human environment }\end{array}$ \\
\hline soil and water management plan & $\begin{array}{l}\text { a documented methodology to monitor the quality and chemical components of the soil and water } \\
\text { and in the meantime provide provisions for any changes that may lead to positive impacts in the long } \\
\text { term }\end{array}$ \\
\hline solar air heater & $\begin{array}{l}\text { a type of solar thermal system in case of which air is heated in a collector and it is either transferred } \\
\text { directly to the interior space or to a storage medium, such as a rock bin }\end{array}$ \\
\hline solar array & a group of solar collectors or solar modules that are connected together \\
\hline solar collector & $\begin{array}{l}\text { a device that is collecting heat by absorbing sunlight and it isused to collect, absorb, and transfer solar } \\
\text { energy to a working fluid }\end{array}$ \\
\hline solar cooling & $\begin{array}{l}\text { the use of solar thermal energy or solar electricity by means of concentrating solar collectors and } \\
\text { absorption chillers to power a cooling appliance and to drive the cooling process }\end{array}$ \\
\hline solar distillation & $\begin{array}{l}\text { the use of solar energy to evaporate water and collect its condensate within the same closed system, } \\
\text { also the process of distilling (purifying) water using solar energy }\end{array}$ \\
\hline solar energy & $\begin{array}{l}\text { an important source of renewable energy transmitted from the sun (solar radiation) used in } \\
\text { technologies such as solar heating, photovoltaics, solar thermal energy and solar architecture }\end{array}$ \\
\hline solar energy collector & see solar collector \\
\hline solar fraction & $\begin{array}{l}\text { the ratio of the amount of input energy contributed by a solar energy system to the total input energy } \\
\text { required for a specific application }\end{array}$ \\
\hline solar furnace & $\begin{array}{l}\text { a structure or device using concentrated solar power and achieving very high temperatures by the use } \\
\text { of reflectors to focus and concentrate sunlight onto a small receiver }\end{array}$ \\
\hline solar gain & $\begin{array}{l}\text { the increase of temperature in a space, object or structure that results from solar radiation, also the } \\
\text { amount of energy absorbed due to solar energy striking }\end{array}$ \\
\hline solar mass & a standard unit of mass and a term used for materials that are used to absorb and store solar energy \\
\hline solar module (panel) & $\begin{array}{l}\text { a solar photovoltaic device producing a specified power output under defined test conditions, usually } \\
\text { composed of groups of solar cells connected in series }\end{array}$ \\
\hline solar pond & $\begin{array}{l}\text { a large scale solar collector with an integrated arrangement for storing heat water, and they can be } \\
\text { used to provide heat for industrial or agricultural processes, building heating and cooling, and to } \\
\text { generate electricity }\end{array}$ \\
\hline solar panel & see photovoltaic module \\
\hline solar thermal electric system & $\begin{array}{l}\text { solar energy conversion technologies converting solar energy to electricity, by heating a working fluid } \\
\text { to power a turbine that drives a generator }\end{array}$ \\
\hline solar thermal systems & $\begin{array}{l}\text { solar energy systems collecting or absorbing solar energy for useful purposes, such as electricity } \\
\text { production }\end{array}$ \\
\hline solid fuels & $\begin{array}{l}\text { various types of solid material used as fuel to produce energy and provide heating, such as wood, } \\
\text { peat, lignite, coal, and manufactured fuels such as pulverized coal, coke, charcoal, briquettes, pellets, } \\
\text { etc }\end{array}$ \\
\hline solid waste management plan & $\begin{array}{l}\text { activities and actions forming a strategy to reduce the quantity of solid waste delivered to landfills, by } \\
\text { reducing the sources of waste and reusing or recycling as much as possible, laying down concrete } \\
\text { goals and objectives together with performance indicators }\end{array}$ \\
\hline
\end{tabular}




\begin{tabular}{|c|c|}
\hline solidity & $\begin{array}{l}\text { the ratio of rotor blade surface area to the frontal area where the rotor passes through in a wind } \\
\text { energy conversion device }\end{array}$ \\
\hline specific heat & see heating capacity \\
\hline stack & $\begin{array}{l}\text { a smokestack or flue for the purpose of exhausting the products of combustion from a combustion } \\
\text { appliance }\end{array}$ \\
\hline stack (heat) loss & sensible and inherent heat found in combustion gases and vapor emitted to the atmosphere \\
\hline stagnation temperature & $\begin{array}{l}\text { the temperature at a stagnation point in a fluid flow, also a condition occuring in a solar collector } \\
\text { when the working fluid does not circulate whilst the sun is shining on the collector }\end{array}$ \\
\hline stall & a condition related to the unexpected or unwanted stopping of the rotor in a wind turbine \\
\hline substrate & a material upon which a photovoltaic cell is applied \\
\hline sustainability & $\begin{array}{l}\text { the enduring capacity in ecology and the use of resources in an environmentally friendly, socially fair } \\
\text { and economically viable manner by meeting current needs during the preservation process of the } \\
\text { environment }\end{array}$ \\
\hline sustainability management systems & $\begin{array}{l}\text { management systems (sets of iterrelated elements) to establish a sustainability policy together with } \\
\text { sustainability objectives in order to achieve them }\end{array}$ \\
\hline sustainable construction & $\begin{array}{l}\text { a relatively new aspect in construction by maximizing the use of renewable energy resources, and } \\
\text { minimizing noise pollution, erosion, destruction of vegetation and negative impacts on air, soil, and } \\
\text { water }\end{array}$ \\
\hline sustainable design & $\begin{array}{l}\text { a common term used in architecture and it refers to the philosophy of designing physical objects by } \\
\text { ways of reducing energy and water consumption, using environmentally friendly materials and in the } \\
\text { meantime maintining harmony with the surroundings }\end{array}$ \\
\hline sustainable landscaping & $\begin{array}{l}\text { a variety of practices referring to an attractive environment that is in balance with the local climate } \\
\text { and requires minimal resource inputs, whilst they are in response to environmental issues }\end{array}$ \\
\hline sustainable tourism & $\begin{array}{l}\text { a concept in which tourism is envisaged as the management of all resources in such a way that } \\
\text { economic, social and cultural needs can be fulfilled by the maintenance of integrity, essential } \\
\text { ecological processes, biological diversity and life support systems }\end{array}$ \\
\hline sustainable utilization & $\begin{array}{l}\text { feasible use of available natural resources in a way and at a rate that does not lead to the long-term } \\
\text { degradation of the environment, therefore it maintains its potential to meet the needs and demands } \\
\text { of both present and future generations }\end{array}$ \\
\hline system mix & $\begin{array}{l}\text { the proportion of electricity distributed by a power provider that is generated from any available } \\
\text { resources such as coal, natural gas, petroleum, nuclear, hydropower, wind, or geothermal energy }\end{array}$ \\
\hline $\begin{array}{l}\text { temperature coefficient (of a solar } \\
\text { photovoltaic cell) }\end{array}$ & $\begin{array}{l}\text { a coefficient describing the relative change of a physical property associated with a given change in } \\
\text { temperature }\end{array}$ \\
\hline therm & a unit of heat energy containing 100,000 British thermal units (BTU) \\
\hline thermal efficiency & $\begin{array}{l}\text { a performance measure of a device using thermal energy, also the efficiency converting a fuel to } \\
\text { energy and useful work }\end{array}$ \\
\hline thermal energy & the internal energy present in a system and developed through the use of heat energy \\
\hline thermal energy storage (TES) & collecting excess thermal energy to store for later use \\
\hline thermal gasification & $\begin{array}{l}\text { the complete thermal breakdown of the biomass particles and their converstion into gas, in which } \\
\text { hydrogen is produced from high-temperature gasifying and low-temperature pyrolysis of biomass }\end{array}$ \\
\hline thermal mass & all materials used for heat storage \\
\hline thermal storage walls & see trombe wall \\
\hline thermodynamic cycle & $\begin{array}{l}\text { a linked sequence of thermodynamic processes in which a working fluid (water, air, ammonia, etc) } \\
\text { successively changes its state (from a liquid to a gas and back to a liquid) for the purpose of producing } \\
\text { useful work or energy or transferring energy }\end{array}$ \\
\hline thermography & $\begin{array}{l}\text { an energy auditing technique in buildings for the purpose of locating areas of low insulation in a } \\
\text { building envelope with the help of a thermographic scanner }\end{array}$ \\
\hline thermophotovoltaic (TPV) cell & $\begin{array}{l}\text { a photovoltaic cell designed to maximize the conversion efficiency at the wavelength of the thermal } \\
\text { radiation, and also part of a basic thermophotovoltaic system }\end{array}$ \\
\hline thermosiphon & the natural and convective flow of air or water due to differences in temperature \\
\hline thermosiphon system & $\begin{array}{l}\text { a passive solar hot water system relying on warm water rising (natural convection) in order to } \\
\text { circulate water through the collectors and to the tank which must be above the collector in this case }\end{array}$ \\
\hline tidal power (tidal energy) & the power converting the energy obtained from ocean tides and generating it into electricity \\
\hline tidal power plant/station & $\begin{array}{l}\text { a plant capturing water in a basin at the peak of a tidal flow, then directing the water through a } \\
\text { hydroelectric turbine as the tide falls }\end{array}$ \\
\hline tip speed ratio (TSR) & $\begin{array}{l}\text { the ratio between the rotational speed of the tip of a blade and the actual velocity of the wind, } \\
\text { referring to wind energy conversion devices }\end{array}$ \\
\hline total internal reflection (TIR) & $\begin{array}{l}\text { TIR is the reflection of the total amount of incident light at the boundary between two media by } \\
\text { trapping the light by refraction and reflection at critical angles inside a semiconductor device }\end{array}$ \\
\hline tracking solar array & $\begin{array}{l}\text { a solar energy array following the path of the sun to maximize the solar radiation incident on the PV } \\
\text { surface }\end{array}$ \\
\hline trailing edge & $\begin{array}{l}\text { the part of a wind energy conversion device blade or airfoil being the last part to contact the wind, } \\
\text { therefore it is the rear edge }\end{array}$ \\
\hline trickle solar collector & $\begin{array}{l}\text { a type of solar thermal collector in which a heat transfer fluid drips out of the header pipe at the top } \\
\text { of the collector, runs down the collector absorber and into a tray at the bottom, all draining to a } \\
\text { storage tank at the end }\end{array}$ \\
\hline trombe wall & $\begin{array}{l}\text { a wall built on the winter sun side of a building with high thermal mass used to store solar energy } \\
\text { passively in a solar home, absorbing solar energy and transferring it to the space behind the wall }\end{array}$ \\
\hline tube-in-plate-absorber & $\begin{array}{l}\text { a type of solar thermal collector where the tubes through which the heat transfer fluid flows are } \\
\text { placed in the absorber plate }\end{array}$ \\
\hline
\end{tabular}




\begin{tabular}{|c|c|}
\hline tube-type collector & $\begin{array}{l}\text { a type of solar thermal collector with tubes (pipes) through which the heat transfer fluid flows and } \\
\text { they are connected to a flat absorber plate }\end{array}$ \\
\hline turbine & $\begin{array}{l}\text { a rotary mechanical device extracting energy from the flow of a fluid (air, steam, water, or hot gases) } \\
\text { and converting it into mechanical motion }\end{array}$ \\
\hline two-tank (dual tank) solar system & $\begin{array}{l}\text { a type of solar thermal system having one tank for storing solar heated water for the purpose of } \\
\text { preheating the water in a conventional water heater }\end{array}$ \\
\hline unglazed solar collector & a type of solar thermal collector having an absorber without a glazed covering \\
\hline variable-speed wind turbines & $\begin{array}{l}\text { in these types of turbines the rotor speed increases and decreases with changing wind speed, } \\
\text { producing electricity with a variable frequency }\end{array}$ \\
\hline vertical ground loop & $\begin{array}{l}\text { a type of closed-loop geothermal heat pump installation, in which the fluid-filled plastic heat } \\
\text { exchanger pipes are laid out horizontally to the ground surface }\end{array}$ \\
\hline voltage & electromotive force or potential difference in electric energy, that is expressed in volts \\
\hline wafer & $\begin{array}{l}\text { a thin sheet of semiconductor (photovoltaic) material made by cutting it from crystalline silicon or } \\
\text { ingot to use in conventional solar cells }\end{array}$ \\
\hline waste management plan & $\begin{array}{l}\text { a detailed methodology for the purpose of: (1) collection, transport, treatment and disposal of waste, } \\
\text { ( } 2 \text { control, monitoring and regulation of the production, collection, transport, treatment and disposal } \\
\text { of waste, and (3) prevention of waste production }\end{array}$ \\
\hline wastewater & $\begin{array}{l}\text { any poor quality used water, typically discharged into the sewage system containing matter and } \\
\text { bacteria in solution or suspension }\end{array}$ \\
\hline water source heat pump & a type of (geothermal) heat pump using ground water or surface water as a heat source \\
\hline water turbine & $\begin{array}{l}\text { a turbine using water pressure to rotate its blades and primarily used to make an electric generator } \\
\text { work }\end{array}$ \\
\hline wind energy (wind power) & $\begin{array}{l}\text { alternative energy derived from the air flow across a landscape caused by the heating of the } \\
\text { atmosphere, earth, and oceans by the sun }\end{array}$ \\
\hline $\begin{array}{l}\text { wind energy conversion system (WECS) or } \\
\text { device }\end{array}$ & $\begin{array}{l}\text { a machine powered by the energy of the wind and used for wind energy convertion into mechanical } \\
\text { energy; it can be used to power machinery and also to operate an electrical generator }\end{array}$ \\
\hline wind generator & $\begin{array}{l}\text { a WECS for the purpose of producing electricity, also a generator converting the mechanical energy of } \\
\text { the wind into electrical energy }\end{array}$ \\
\hline wind generator blade & $\begin{array}{l}\text { the wide, long part of a wind generator that is shaped in order to generate the maximum power from } \\
\text { the wind }\end{array}$ \\
\hline windmill & a WECS used to grind grain, and typically having a high-solidity turbine rotor \\
\hline windpower curve & $\begin{array}{l}\text { a graph explaning the relationship between the power produced from the wind and the speed of the } \\
\text { wind; the power generated from the wind increases reciprocally with the cube of the wind speed }\end{array}$ \\
\hline wind power plant (wind generating station) & $\begin{array}{l}\text { a group of wind turbines that are physically interconnected to a joint power provider system through } \\
\text { a system of generators or transformers, distribution lines, and (normally) one substation }\end{array}$ \\
\hline wind resource assessment & $\begin{array}{l}\text { the process of discribing the wind resource together with its energy potential, for a specific site or } \\
\text { geographical area }\end{array}$ \\
\hline wind rose & $\begin{array}{l}\text { a diagram indicating the average percentage of time that the wind blows from various directions, } \\
\text { measured on a monthly or an annual basis }\end{array}$ \\
\hline wind speed & a fundamental atmospheric rate of wind flow caused by the movement of air without impediment \\
\hline wind speed profile & $\begin{array}{l}\text { a profile corresponding to how the wind speed variea with height above the surface of the ground or } \\
\text { water }\end{array}$ \\
\hline wind turbine & a wind energy conversion device producing electricity equipped with one, two, or three blades \\
\hline wind turbine rated capacity & $\begin{array}{l}\text { it is the amount of power that a wind turbine produces at its rated wind speed, generally } \\
\text { corresponding to the point at which the conversion efficiency reaches its maximum. }\end{array}$ \\
\hline
\end{tabular}




\section{UNIT 1 RENEWABLE ENERGY AND RURAL DEVELOPMENT - Part 1}
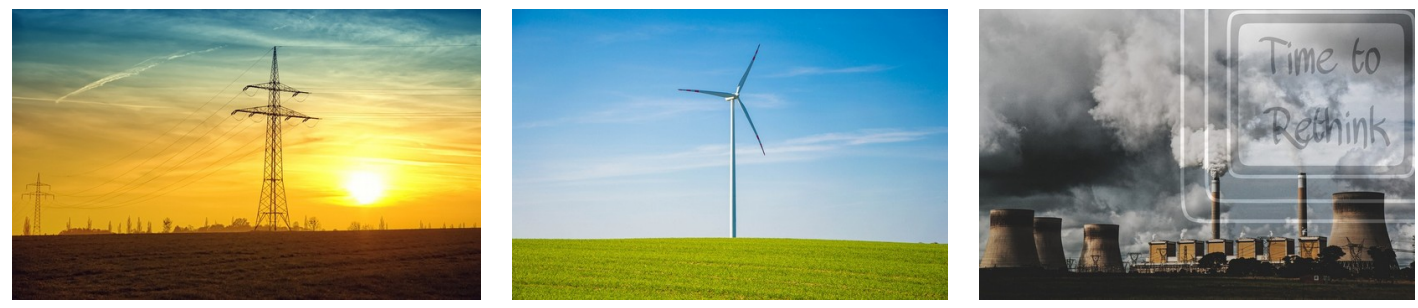

\section{Read the following text twice.}

Our everyday activities depend heavily on energy. Traditional fossil fuels like coal, oil and natural gas, however, pollute the environment, and it is becoming more and more expensive to find and extract them. Furthermore, we are running out of them. So, it is very urgent to find new sources to meet the increasing energy needs of the growing population of the Earth.

Eco-friendly, or green energy sources like solar and wind power, hydropower and biomass do not have a negative impact on the environment. They are also renewable, which means we will never run out of them as they are continuously replenished.

to extract - to take out, to remove

to replenish - to make full or complete again (e.g. 'He replenished my glass with mineral water.')

Which of these energy resources are renewable?

wind energy

yes

coal

no

oil

no

solar energy yes

hydropower yes

natural gas no

biomass yes

Match the words to form phrases. You can go back to the text if you don't remember a phrase.

fossil

depend

to have

fuel

to meet

on something

an impact on something

needs

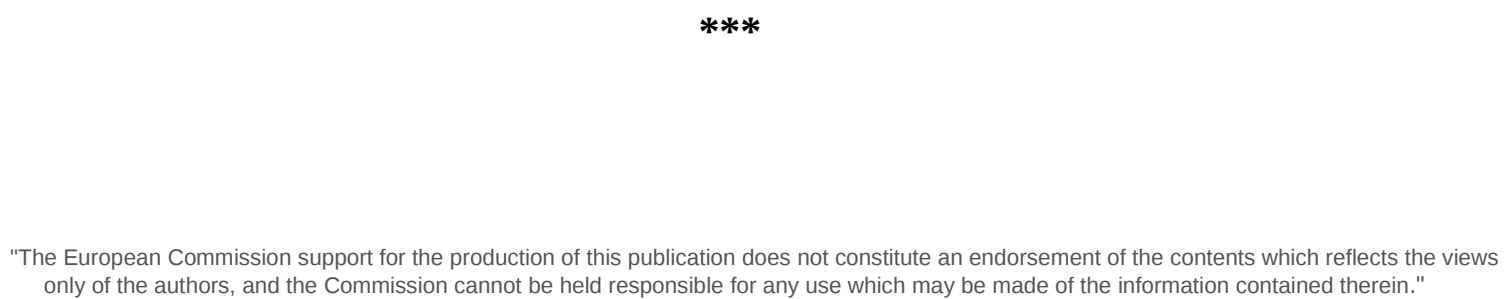




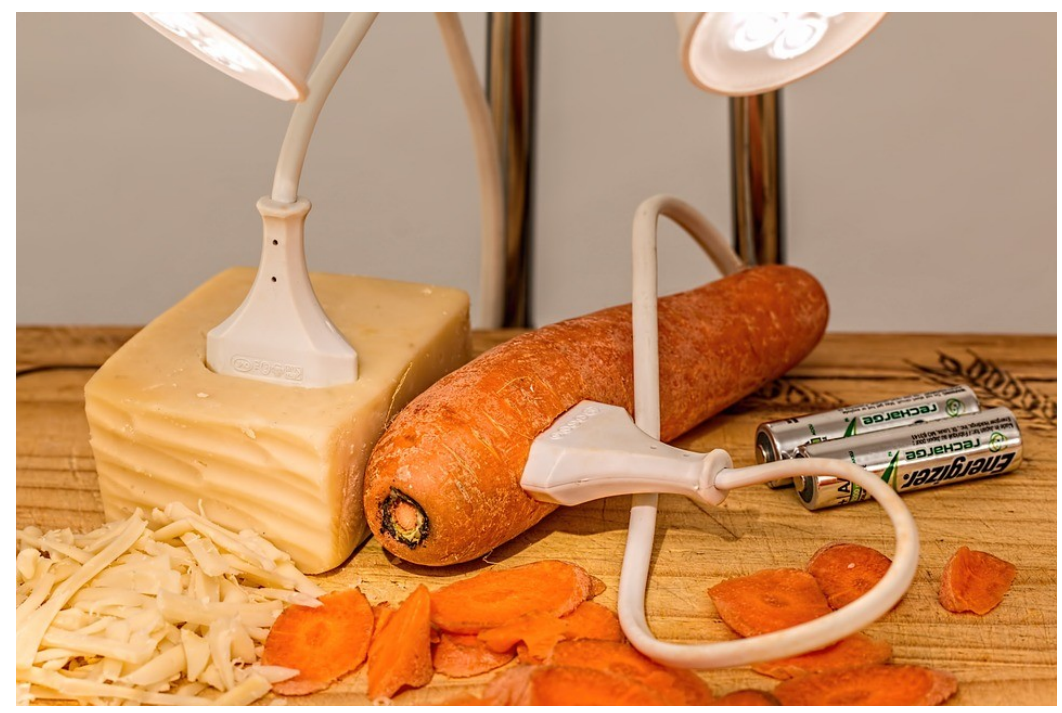

\section{Read the text below about the difference between renewable and non-renewable energy, and try to understand as much as possible. Don't use a dictionary.}

\section{Renewable and non-renewable energy resources}

Over the last 200 years, an ever-increasing proportion of our energy has come from nonrenewable sources such as oil and coal. While demand for energy rises, these resources are running out and scientists are exploring the potential of renewable sources of energy for the future.

All life on earth is sustained by energy from the sun. Plants and animals can store energy and some of this energy remains with them when they die. It is the remains of these ancient animals and plants that make up fossil fuels.

Fossil fuels are non-renewable because they will run out one day. Burning fossil fuels generates greenhouse gases and relying on them for energy generation is unsustainable. Hence the need to find more renewable, sustainable ways of generating energy. Renewable or infinite energy resources are sources of power that quickly replenish themselves and can be used again and again.

Estimates from international organisations suggest that if the world's demand for energy from fossil fuels continues at the present rate, oil and gas reserves may run out within some of our lifetimes. The estimated length of time left for oil is 50 years, while for natural gas it is 70 years. Coal is expected to last longer, about 250 years. 


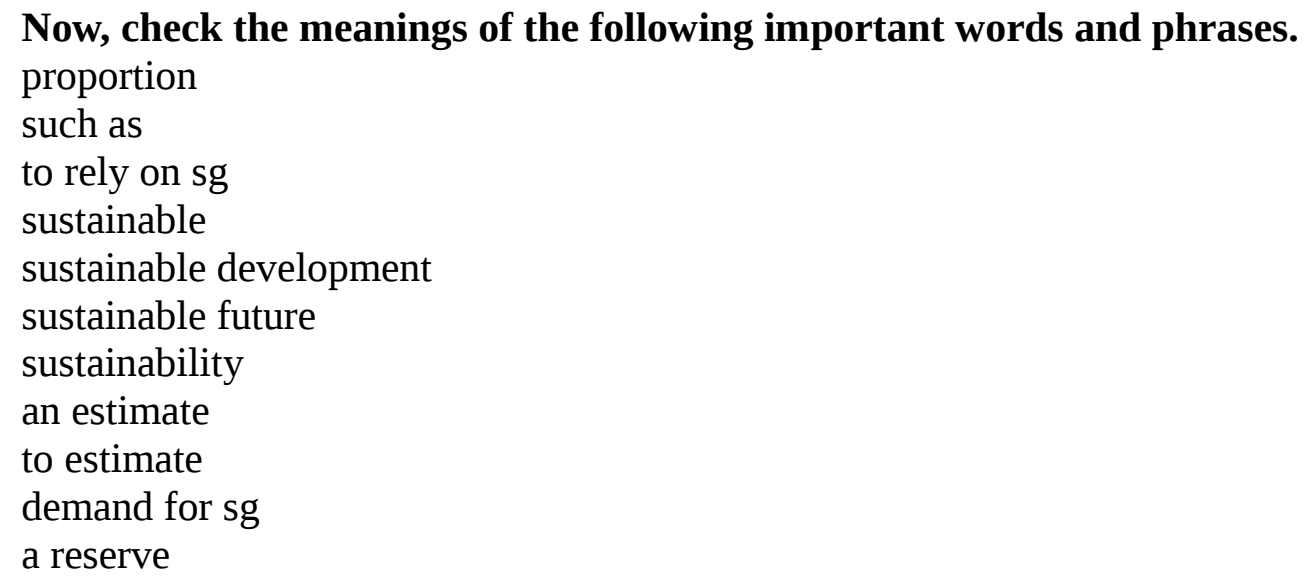

Read the text again, and then look at these sentences. Are they true or false on the basis of the text?

1. About 200 years ago, people used a lot of oil and coal. false

2. All life on earth depends on the energy of the sun. true

3. If we rely on non-renewable energy in the future, our life will be sustainable. false

4. Greenhouse gases are generated by burning fossil fuels. true

5. The energy in animals and plants comes from the sun. true

6. The estimated time left for coal reserves is 250 years, if demand does not grow. false

Match the words with their definitions.

proportion

such as

demand part, share

for example

strong need

\section{THE PASSIVE VOICE}

Look at the sentence below.

\section{Renewable energy resources can be used again and again.}

It means: You can use renewable energy resources again and again. But the first sentence is more elegant. It is a passive sentence, while the second one is active. In formal texts, you will find a lot of passive sentences so it is important to understand them.

\section{How to form the passive voice?}

It has two elements: $\mathbf{b e}+\mathbf{V}_{\mathbf{3}}$

You must always use 'be' in the right tense and form. So, if your sentence is in the present tense, you should use 'am', 'is' or 'are'. If it is in the past tense, use 'was' or 'were'. After auxiliary verbs like 'will', 'must', 'can', 'should' etc, you must use the infinitive form 'be'. "The European Commission support for the production of this publication does not constitute an endorsement of the contents which reflects the views
only of the authors, and the Commission cannot be held responsible for any use which may be made of the information contained therein." 
Let's see some examples:

- $\quad$ The passive voice is used in formal texts.

- $\quad$ This house was built in 1972.

- $\quad$ Renewable energy resources weren't considered important 100 years ago.

- $\quad$ Wind energy will be used in more countries in the future.

- $\quad$ The energy of the sun has been used for a long time.

Complete the following sentences with the correct forms of 'be'.

Next year, a new power plant will built near our town. (be)

Non-renewable energy sources must used less often. (be)

Wood first used as a source of energy thousands of years ago, when early humans learnt to make fire. (was)

How long has wind energy used by humans? (been)

Oil and natural gas should replaced by renewable energy sources. (be)

\section{Forum topic:}

What is the difference between global warming and climate change? 


\section{UNIT 2
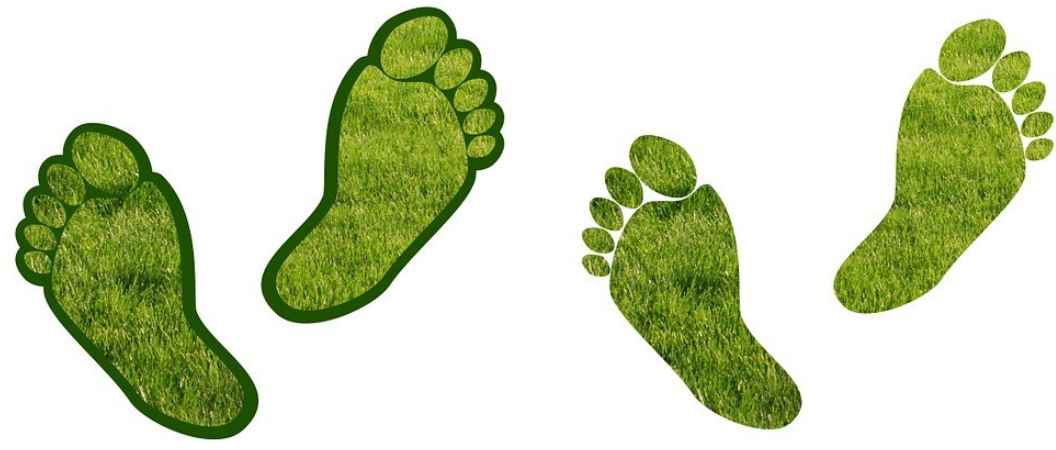

The carbon footprint

As we need more and more energy, it is very important to choose sources that have less negative impact on the environment. As CO 2 is one of the most important greenhouse gases, the negative impact of our activities is usually measured by the amount of carbon dioxide we emit, which is called our carbon footprint.

to measure - to calculate the size of sg

amount - quantity, number

to emit - to let out, to release

Watch this video that explains the meaning of the carbon footprint.

https://www.youtube.com/watch?v=8q7 aV8eLUE

\section{Are these sentences true or false on the basis of the video?}

1. Your carbon footprint is a mark you leave upon the environment with every action that releases carbon dioxide and other harmful gases.

true

2. Burning fossil fuels causes harmful greenhouse gases.

true

3. The more fuel is used, the smaller the carbon footprint will be.

false

4. You have no carbon footprint when you brush your teeth.

false

5. You can reduce your carbon footprint by choosing less polluting options.

true

Match the words to make phrases.

climate

to reduce

to release harmful

change

to emit carbon

your carbon footprint

gases

dioxide 


\section{Read the text below about the benefits of renewable energy. Try to understand it without a dictionary. \\ Benefits of Renewable Energy Use}

Renewable energy - wind, solar, geothermal, hydroelectric, and biomass - provides a lot of benefits for our climate, our health, and our economy.

Human activity is overloading our atmosphere with carbon dioxide and other greenhouse gas emissions, which trap heat, steadily drive up the planet's temperature, and create significant and harmful impacts on our health, our environment, and our climate.

Electricity production accounts for more than one-third of U.S. greenhouse gas emissions, with the majority generated by coal-fired power plants, which produce approximately 25 percent of total U.S. greenhouse gas emissions; natural gas-fired power plants produce 6 percent of total emissions. In contrast, most renewable energy sources produce little to no greenhouse gas emissions. (...)

Generating electricity from renewable energy rather than fossil fuels offers significant public health benefits. (...) Replacing fossil fuels with renewable energy has been found to reduce premature mortality and lost workdays, and it reduces overall health care costs. (...)

Compared with fossil fuel technologies, which are typically mechanized and capital intensive, the renewable energy industry is more labor-intensive. This means that, on average, more jobs are created for each unit of electricity generated from renewable sources than from fossil fuels. (...)

While renewable facilities require upfront investments to build, once built they operate at very low cost and, for most technologies, the fuel is free. As a result, renewable energy prices are relatively stable over time. (...) In contrast, fossil fuel prices can vary dramatically and are prone to substantial price swings.

http://www.ucsusa.org/clean_energy/our-energy-choices/renewable-energy/public-benefits-of-renewable.html\#.VpjQVKSVvb0

There are six paragraphs in the previous text. Answer the questions about their contents. Write the number(s) of the paragraph in the box.

1. Which paragraph is about the health benefits of renewable energy? (4)

2. Which paragraphs are about the environmental benefits of renewable energy? $(2,3)$

3. Which paragraphs are about the economic benefits of renewable energy? $(5,6)$

Choose the best answer on the basis of the previous text.

Renewable energy has ...

a) a lot of benefits.

b) very few benefits.

Carbon dioxide is a

a) greenhouse gas.

yes

b) renewable gas. 


\section{Open Educational Resources for online course of \\ Technical English for Renewable Energy}

Electricity generation

a) is responsible for more than $1 / 3$ of greenhouse gas emissions in the US. yes

b) reduces greenhouse gas emissions by one-third in the US.

Most of the energy in the US is

a) generated by coal-fired power plants.

yes

b) natural gas-fired power plants.

Premature mortality means

a) early deaths.

yes

b) early births.

Renewable energy facilities (e.g. wind farms, solar panels) are expensive ... and cheap ... .

a) to use; to build

b) to build; to use

yes

Now, you can check the meanings of the following words in a dictionary. They are the most important words from the text that you should know.

benefit

economy

to trap heat

to account for 30 percent

majority

power plant

approximately

to generate electricity / to produce electricity

public health

to replace sg with sg

Compared with sg, ...

capital

labour

on average

to require

investment

to operate

cost

to vary dramatically

\section{Match the words in bold with their meanings.}

1. Coal-fired power plants emit a lot of greenhouse gases. release, let out

2. Greenhouse gases trap heat, and drive up the planet's temperature. capture, catch

3. Natural gas-fired power plants account for approximately $5 \%$ of total emissions. about

4. The renewable energy industry is labour-intensive. needs a lot of workers

\footnotetext{
"The European Commission support for the production of this publication does not constitute an endorsement of the contents which reflects the views
} only of the authors, and the Commission cannot be held responsible for any use which may be made of the information contained therein." 


\section{Open Educational Resources for online course of Technical English for Renewable Energy}

5. Renewable energy facilities need a lot of upfront investments. in advance, at the beginning

6. When they are built, wind farms operate at very low costs. work

\section{Which type of energy source do the following statements refer to?}

They account for the majority of greenhouse gas emissions.
a) fossil fuels
yes
b) renewable energy sources

They can reduce health care costs.
a) fossil fuels
b) renewable energy sources
yes

They are more capital intensive.

a) fossil fuels

b) renewable energy sources yes

They are less labour-intensive.
a) fossil fuels
yes
b) renewable energy sources

Their prices may change dramatically.
a) fossil fuels
yes
b) renewable energy sources

\section{Forum topic:}

Watch this video: https://www.youtube.com/watch?v=lWUaE-Oaek8

What is the story of Gratiot County? Summarize it in 5 sentences. 


\section{UNIT $3 \quad$ RENEWABLE ENERGY AND RURAL DEVELOPMENT - Part 3}

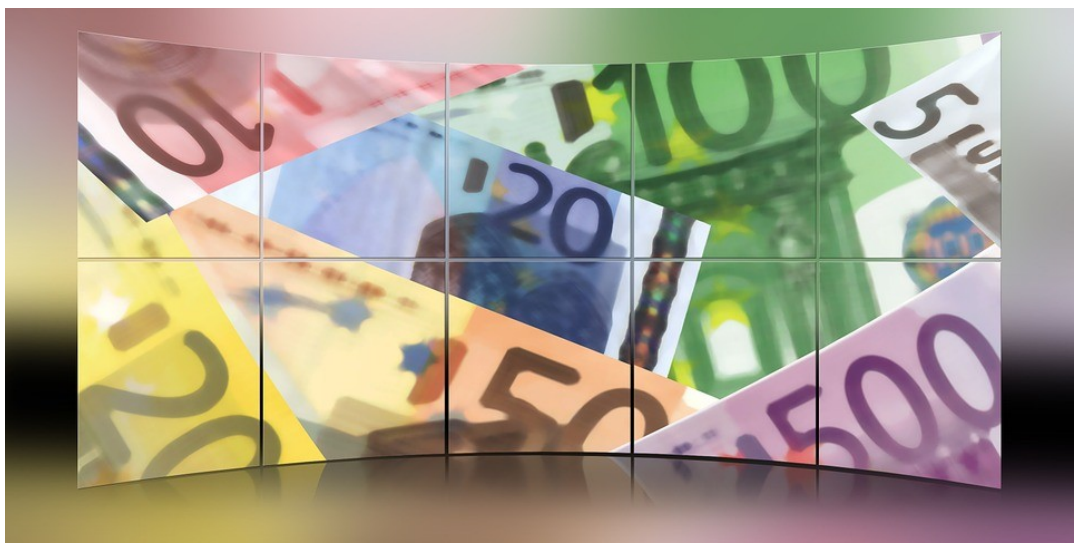

Check the meanings of the following words and phrases in your dictionary.

$\begin{array}{llll}\begin{array}{l}\text { lease payments } \\ \text { manufacturing }\end{array} & \begin{array}{l}\text { installation } \\ \text { maintenance }\end{array} & \begin{array}{l}\text { property tax } \\ \text { construction }\end{array} & \text { income tax }\end{array}$

Now, fill in the gaps with the most suitable words from the list. The chosen word should mean the same as the one in brackets.

1. This car ... (making) company sold over 200,000 cars last year. (manufacturing)

2. The local government spends a lot of money on road ... (building). (construction)

3. Both the price of a solar panel and the cost of its ... (putting in place and making it ready for use) are high. (installation)

4. Car ... (keeping in good condition) tasks in winter include installing your winter tires, checking your battery and buying a de-icer. (maintenance)

5. How much ... (part of your salary paid to the government) did you pay in 2014? (income tax)

6. Landowners have to pay a ... (part of the value of a building or land paid to the government) based on the value of their lands every year. (property tax)

7. Wind energy businesses pay high amounts of ... (money paid for using something without buying it) to farmers whose lands they use to operate their wind mills. (lease payments) 


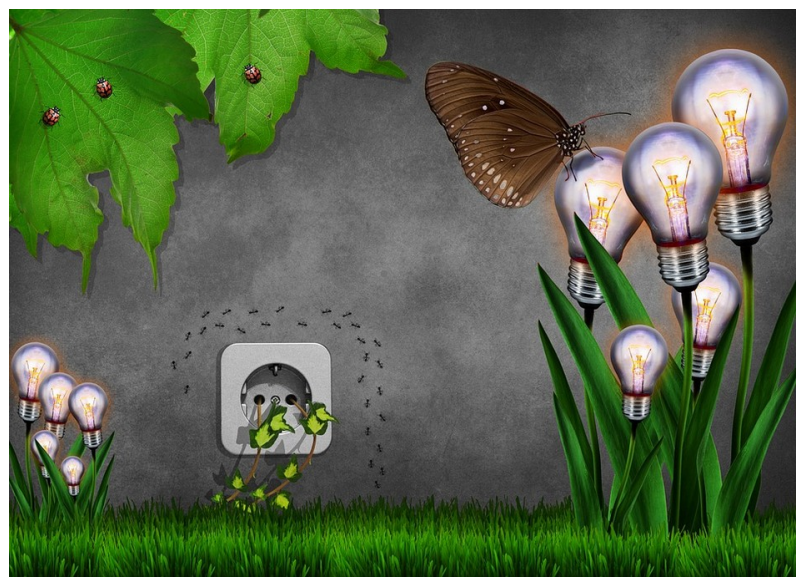

You have already read about the benefits of using renewable energy sources. From this text, you will learn what the economic benefits are.

\section{Economic benefits of using renewable energy sources:}

1. As it is labour-intensive, more jobs are created for each unit of electricity generated from renewable sources than from fossil fuels. For example, jobs in the wind energy industry include the following areas: manufacturing, project development, construction, installation, operations, maintenance, transportation, logistics, financial, legal and consulting services.

2. Renewable energy businesses use primarily local workers, so they support local development, which is particularly important in disadvantaged rural areas.

3. A rise in the number of jobs has a positive economic effect on households and businesses. In a community, even businesses unrelated to the renewable energy industry can benefit from the positive economic impact, since people with higher incomes spend more on other products and services.

4. Local governments get money from renewable energy businesses in different forms: property and income taxes, lease payments (e.g. from wind energy businesses for using the land).

5. Energy prices become more stable, as the price of locally generated energy is not influenced by dramatic changes in global demand. Furthermore, the cost of generating energy from renewable sources is declining steadily, so it will be cheaper and cheaper.

manufacturing - making, producing

construction - building

installation - putting in place and making ready for use

maintenance - keeping in good condition

property tax - tax on buildings or land

lease payments - money paid for using sg (without buying it)

\section{Match the sentence halves.}

1. Renewable energy generation is labour-intensive so it creates more jobs.

2. Renewable energy businesses employ local people so they contribute to the development of local communities.

"The European Commission support for the production of this publication does not constitute an endorsement of the contents which reflects the views only of the authors, and the Commission cannot be held responsible for any use which may be made of the information contained therein." 


\section{Open Educational Resources for online course of Technical English for Renewable Energy}

3. Renewable energy businesses pay income taxes and property taxes to local authorities.

4. Wind farms and solar parks lease payments to landowners.

5. The price of renewable energy is more stable as it is not influenced by global demand changes.

These are the most important words and phrases for this topic. Read them through, and check the meanings of the unknown ones.

manufacturing

construction

installation

operation

maintenance

disadvantaged

rural area

to have a positive / negative effect / impact on sg

household

community

local government / local authorities

property tax

income tax

to lease sg

lease payments

stable prices

to decline

declining costs

Many people mix up 'economic' and 'economical'. But these words have different meanings. Look at these two sentences:

The country's economic situation is almost the same as last year.

LED lamps are more economical than neon lamps.

'economic' is always about something that is connected to the economy, while 'economical' means cheap, not wasting money or energy.

Some more examples:

- The new law may cause economic disaster in the country.

- The country's economic growth slowed down in 2013.

- The most economical way to see the Amazon River is by air.

- Hybrid cars are more economical. 


\section{Decide which one is correct.}

Their heating system is more ... than ours.
a) economic
b) economical
yes

The majority of the population are already experiencing the results of the ... reforms.
a) economic
b) economical
yes

The bicycle is more ... and healthier than the car.
a) economic
b) economical
yes

Cars have become more ... in the past few years.
a) economic
b) economical
yes

There was a drop in the unemployment rate due to ... development.
a) economic
b) economical
yes

Try to be ... with the water. We only have 4 litres left.
a) economic
b) economical
yes

Most of the shops in our town closed down during the ... crisis.
a) economic
b) economical
yes

They want to buy a small, ... car.
a) economic
b) economical
yes

\section{Match the words with their meanings.}

revenue all the money a company gets during a specific period to pay off

tax to be advantageous, to have benefits

cost money that you have to pay to the government or other authorities the money that is needed to pay for doing something 
The following words are connected to jobs. Look at their meanings. If you don't know them in your language, look them up in your dictionary.

to employ - to give somebody a job

an employee - a worker

an employer - a company who gives jobs to people

unemployment - a situation when some people don't have jobs

labour - workforce, workers; work

wage - money that a person earns, usually according to how many hours or days they work each week

salary - money that a person earns each month or year

Now, fill in the gaps with the correct words in the sentences below. Don't forget to use them in the correct forms.

1. The biomass power plant ... 320 people. (employs)

2. All the workers got their ... at the end of the week. (wages)

3. As the company had a very successful year, the wind construction managers' ... was raised. (salaries)

4. SolarFuture, a solar energy ... expects to see a dramatic rise in the use of solar energy in the following ten years. (employer)

5. The rate of ... decreased after the wood pellet manufacturing plant was built. (unemployment)

6. People living in rural, agricultural areas are typically disadvantaged in the ... market. (labour)

7. At the moment, there are approximately $3000 \ldots$ working in the wind farm construction sector. (employees)
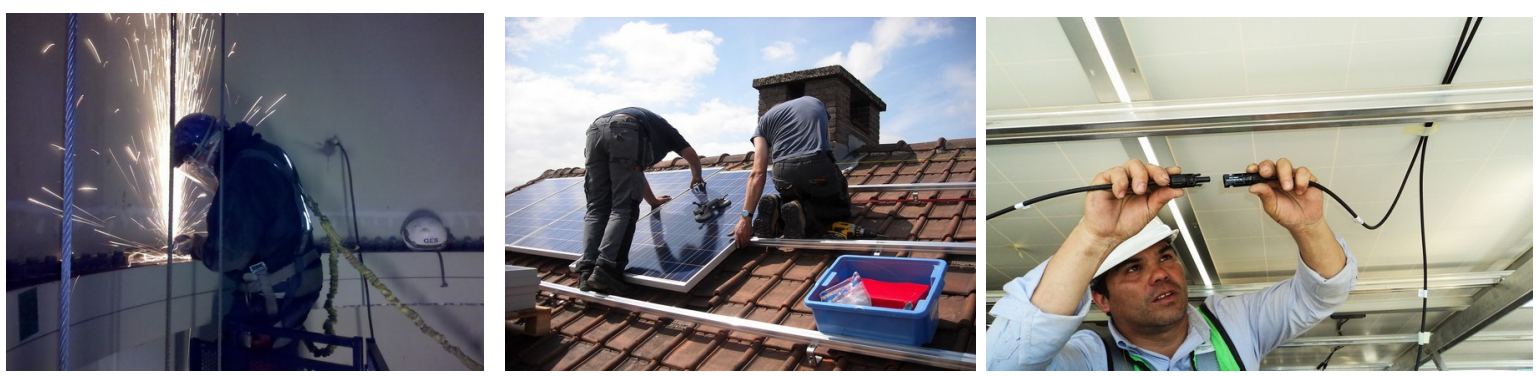

$* * *$

\section{Forum topic:}

Watch this video: https://www.youtube.com/watch?v=-2-phLM-ALA

What is the story of Goldendale? Summarize it in 5 sentences.

"The European Commission support for the production of this publication does not constitute an endorsement of the contents which reflects the views only of the authors, and the Commission cannot be held responsible for any use which may be made of the information contained therein." 


\section{UNIT $4 \quad$ PHOTOVOLTAIC ENERGY - Part 1}
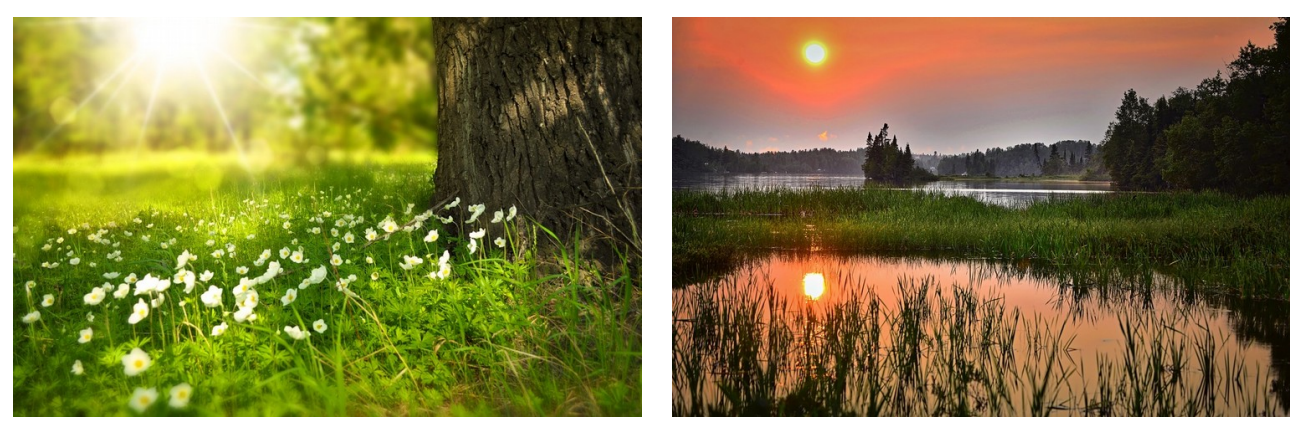

\section{Read the text below. There are some words explained for you.}

\section{Interesting Facts About The Sun}

- In a single day, the Sun provides about 300 BTUs $^{1}$ of heat per square foot $^{2}$ of the Earth's surface.

- The amount of solar energy that strikes the Earth in one hour is more than enough to provide all of the Earth's energy needs for a complete year.

- Approximately $50 \%$ of the sun's energy is absorbed ${ }^{3}$ by the Earth's surface ${ }^{4}$, while another $30 \%$ is reflected ${ }^{5}$ back from the Earth's surface.

- Depending on where you are in the world, and the angle ${ }^{6}$ of the terrain ${ }^{7}$, about 1,000 watts of solar energy reaches the Earth's surface per hour per square meter.

\footnotetext{
${ }^{1} 1$ BTU (British Thermal Unit) - a traditional unit of work equal to about 1055 joules

${ }^{2} 1$ foot -30.48 centimetres

${ }^{3}$ to absorb - to take in

${ }^{4}$ surface - the top layer of something

${ }^{5}$ to reflect - the light shines back off something

${ }^{6}$ angle - the direction from which something comes (It is measured in degrees.)

${ }^{7}$ terrain - an area of land with a particular surface
}

\section{General Solar Energy Facts}

- Solar energy is healthier for the environment than traditional fossil related forms of energy.

- Solar energy has many positive uses, such as the production of electricity through photovoltaic ${ }^{1}$ cells, and the direct heating of water for a variety ${ }^{2}$ of other applications ${ }^{3}$.

- Solar energy can also be used to heat swimming pools, to power ${ }^{4}$ cars, for attic ${ }^{5}$ fans $^{6}$, calculators and other small appliances ${ }^{7}$. It produces lighting for indoors and outdoors. You can even cook food with solar energy.

- Solar energy is becoming more and more popular. The worldwide demand ${ }^{8}$ for solar energy is currently much greater than the amount we have been able to supply ${ }^{9}$. 
${ }^{1}$ photovoltaic (PV) cell - equipment that changes light into electricity

${ }^{2}$ a variety of $\mathrm{sg}-\mathrm{a}$ number of different things

${ }^{3}$ application - use

${ }^{4}$ to power - to give power to a machine or vehicle

${ }^{5}$ attic - the room directly under the roof of a house

${ }^{6}$ fan - machine that turns the air to make it less hot

${ }^{7}$ appliance - machine in a home, e.g. coffee maker

${ }^{8}$ demand - all the things people want to buy

${ }^{9}$ supply - all the things that are available to buy or use

These are the most important words in the text. Check them in your dictionary if you don't know them in your language.

to strike

to provide

square metre

surface

to absorb

to reflect back

angle

terrain

to convert sg into sg

to power sg

appliance

to supply

Read the text again, and then complete the sentences with the correct words.

The amount of solar energy that strikes the Earth in one ... is more than enough to provide all of the Earth's energy needs for a complete year.
a) hour
yes
b) year

Solar energy is less ... than fossil fuels.

a) disadvantaged

b) harmful yes

The amount of solar energy that reaches the Earth's surface per hour per square metre depends on where you are in the world and the ... of the terrain.
a) angle
yes
b) degree

PV ... convert light into electricity.
a) cells
yes
b) cell

Solar energy can be used to heat water and provide electricity for your ... .
a) applications
b) appliances

yes "The European Commission support for the production of this publication does not constitute an endorsement of the contents which reflects the views
only of the authors, and the Commission cannot be held responsible for any use which may be made of the information contained therein." 
Techical English for Renewable Energy
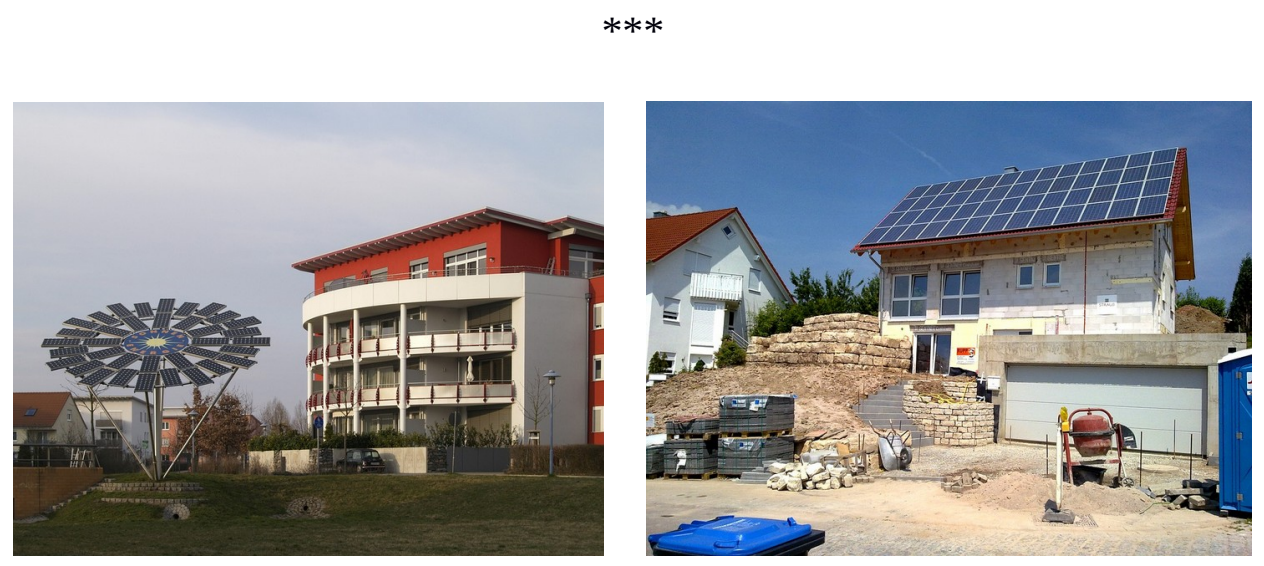

Read this text about the advantages of having PV panels in your home.

Benefits of Solar Panel Electric Power Systems for Homes

If you like the thought of contributing to the efforts of making the earth a better place to live, or if you like money, you'll love solar energy. There are a myriad of great reasons to install a photovoltaic solar power generation system in your home or commercial building. Here are a few:

- A solar energy system adds to your property value.

- Home based solar power is a quiet, nearly maintenance free, continuous source of electricity.

- Solar electric systems reduce pollution and CO2 emissions by generating electrical power using radiant sunlight that can replace electricity that comes from coal-fired electrical plants.

- Many states including California, Massachusetts, New Jersey, Maryland, Texas and Arizona offer $\$ 0$ down installation plans that immediately lower your electric bill and cost nothing to install or maintain.

http://solarenergy.com/

\section{Match the words with their meanings. The text can help you.}

to contribute to sg

effort

property

maintenance free

$\$ 0$ down installation plan to help achieve a goal

hard work that you do in order to achieve a goal house or land no money is needed to keep it in good, working condition when you buy a solar system on credit and no money has to be paid before installation 
Check the meanings of these words if necessary. Then, complete the sentences with the most suitable words from the box. There is one extra word.

$\begin{array}{lll}\text { value } & \text { nearly } & \text { generate } \\ \text { PV } & \text { contribute } & \text { valuable }\end{array}$

1. If you want to ... to environmental protection, you should install PV panels in your home. (contribute)

2. Solar energy systems add to the ... of a property, which means they will become more expensive. (value)

3. Solar electric systems are absolutely quiet and ... no money has to be spent on maintenance. (nearly)

4. Solar energy systems use radiant sunlight to ... electricity. (generate)

5. If you choose a $\$ 0$ down installation plan, it means you don't have to pay any money before ... panels are installed. (PV)

6.

Read the following news story about the plans of an investment project in the United States. Try to understand as much as possible without a dictionary. If necessary, read it two or three times.

\section{Cypress Creek Renewables Plans \$12 Million Solar Project In Saluda County, South} Carolina

Area Development News Desk

January 12, 2016

Cypress Creek Renewables, a company that specializes in the ownership and development of long-term solar energy projects, has taken first steps toward investing \$12 million in solar energy projects in Saluda County, South Carolina.

The projects, a nine-megawatt facility located off of S.C. Highway 121 in Saluda and a fourmegawatt facility located off of Columbia Highway in Saluda, are expected to be fully operational by the end of 2016. One megawatt of solar energy is enough to provide inexpensive, secure, clean energy to approximately 200 South Carolina homes.

"Local solar projects help to grow the economy by providing clean, renewable energy for homes and businesses. Working in partnership with our utility partners, local leaders, and the state of South Carolina, gives us the opportunity to help build an energy-independent future,” said Cypress Creek Renewables CEO Matthew McGovern.

"It's very exciting to be part of projects like these that are helping to reshape South Carolina's energy future. This would not be possible without the support of the local community and all of our development partners," said Southern Current, LLC Principal/Chief Development Officer Paul Fleury.

http://www.areadevelopment.com/newsitems/1-12-2016/cypress-creek-renewables-saluda-county-south-carolina346532.shtml 


\section{Open Educational Resources for online course of Technical English for Renewable Energy}

\section{Choose the best answer on the basis of the text.}

1. Cypress Creek Renewables has ... solar projects in South Carolina.
a) invested a lot of money in
b) decided to put $\$ 12$ million into yes
c) spent $\$ 12$ million on

2. The two planned solar parks will ... later this year.
a) start operation
yes
b) close down
c) be partly operational

3. The homes and businesses of ... will get clean, renewable energy.
a) the county
yes
b) the country
c) Cypress Creek

4. Cypress Creek Renewables works in partnership with ..., local leaders, and the State of South Carolina.
a) useful partners
b) utilized companies
c) companies that sell electricity, gas to the public
yes
5. Projects like these help ... the state's energy industry.
a) shape
b) modification
c) transform
yes

\section{Forum topic:}

Some scientists think that installing a lot of solar panels in the Sahara desert could provide clean energy for the whole world. Nobody would need any fossil fuels. What is your opinion? Give reasons.

(If you want, you can read about this here: http://www.bbc.com/news/science-environment34987467) 


\section{UNIT $5 \quad$ PHOTOVOLTAIC ENERGY - Part 2}

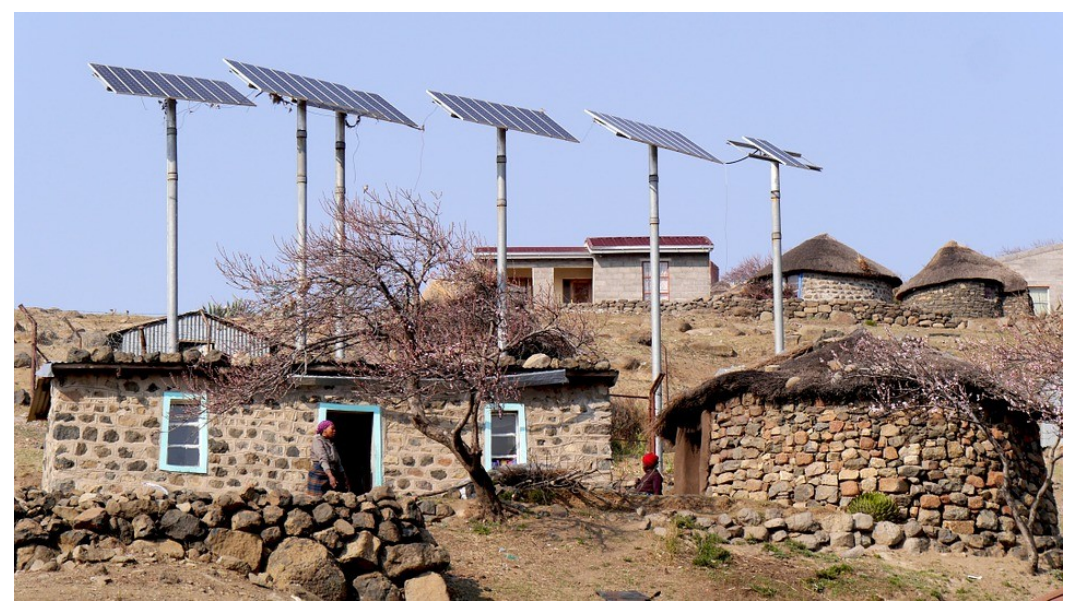

\section{Read this text from the website of an American solar energy company.}

\section{Solar energy}

Solar power is energy from the sun that is converted into thermal or electrical energy. Solar energy is the cleanest and most abundant renewable energy source available, and the U.S. has some of the richest solar resources in the world. Modern technology can harness this energy for a variety of uses, including generating electricity, providing light or a comfortable interior environment, and heating water for domestic, commercial, or industrial use.

There are several ways to harness solar energy: photovoltaics (also called solar electric), solar heating \& cooling, concentrating solar power (CSP), and passive solar.

The first three are active solar systems, which use mechanical or electrical devices that convert the sun's heat or light to another form of usable energy. Passive solar buildings are designed and oriented to collect, store, and distribute the heat energy from sunlight to maintain the comfort of the occupants without the use of moving parts or electronics.

Solar energy is a flexible energy technology: solar power plants can be built as distributed generation (located at or near the point of use) or as a central-station, utility-scale solar power plant (similar to traditional power plants). Some utility-scale solar plants can store the energy they produce for use after the sun sets.

http://www.seia.org/about/solar-energy

Now, check the meanings of the most important words in your dictionary.

to convert sg into sg

to harness

to generate electricity

domestic

commercial

industrial

device

"The European Commission support for the production of this publication does not constitute an endorsement of the contents which reflects the views only of the authors, and the Commission cannot be held responsible for any use which may be made of the information contained therein." 
to orient a building

to store heat

to distribute

(public) utility company

Match the technologies with their descriptions using the text above. Write the abbreviations in the boxes. (A hallgatónak csak a rövidítést kell beírnia a kihagyott helyre.)

SHC: solar heating \& cooling

CSP : concentrating solar power

PV : photovoltaics

PST : passive solar techniques

1. ... technologies collect the thermal energy from the sun and use this heat to provide hot water, space heating, cooling, and pool heating for residential, commercial, and industrial applications. solar heating \& cooling (SHC)

2. ... is a technology that converts light into electricity with the help of certain materials that can absorb photons and release electrons. photovoltaics (PV)

3. ... include choosing special building materials that can collect, store and distribute the heat of the sun in the winter, and reject it in the summer. It also means orienting buildings so that they can use the heat and light of the sun in the most efficient way. (PST)

4. ... plants use mirrors and lenses to concentrate the energy of the sunlight and convert it into heat to create steam. This steam drives turbines or engines that create electricity. concentrating solar power (CSP)

Using the information in the previous task, write a ' + ' in the boxeds that are true for that type fo solar technology, and write a '-' if it is not true.

\begin{tabular}{|l|c|c|c|c|}
\hline & active solar systems & $\begin{array}{c}\text { passive solar } \\
\text { systems }\end{array}$ & electricity & heat \\
\hline photovoltaics & + & - & + & - \\
\hline $\begin{array}{l}\text { solar heating } \\
\text { and cooling }\end{array}$ & + & - & - & + \\
\hline $\begin{array}{l}\text { concentrating } \\
\text { solar power }\end{array}$ & + & - & + & - \\
\hline $\begin{array}{l}\text { passive solar } \\
\text { techniques }\end{array}$ & - & + & - & + \\
\hline
\end{tabular}


Match the words with their meanings. If necessary, look them up in your dictionary.

PV

DC

photovoltaic

AC

direct current

grid alternating current network of lines that distribute electricity from power stations to people

Watch the following video about how PV panels work.

https://www.youtube.com/watch?v=f8 NdUb8sjc

Watch the video again, and decide whether the statements are true or false.

PV panels don't work on cloudy days.

false

The PV panels create direct current.

true

An inverter converts the AC into DC.

false

We use alternating current in our homes.

true

Your everyday appliances are connected to the mains consumer unit.

true

At night, your home gets electricity from the grid.

true

Any solar power that you don't use is lost.

false

\section{Number the pictures to put them into the correct order.}
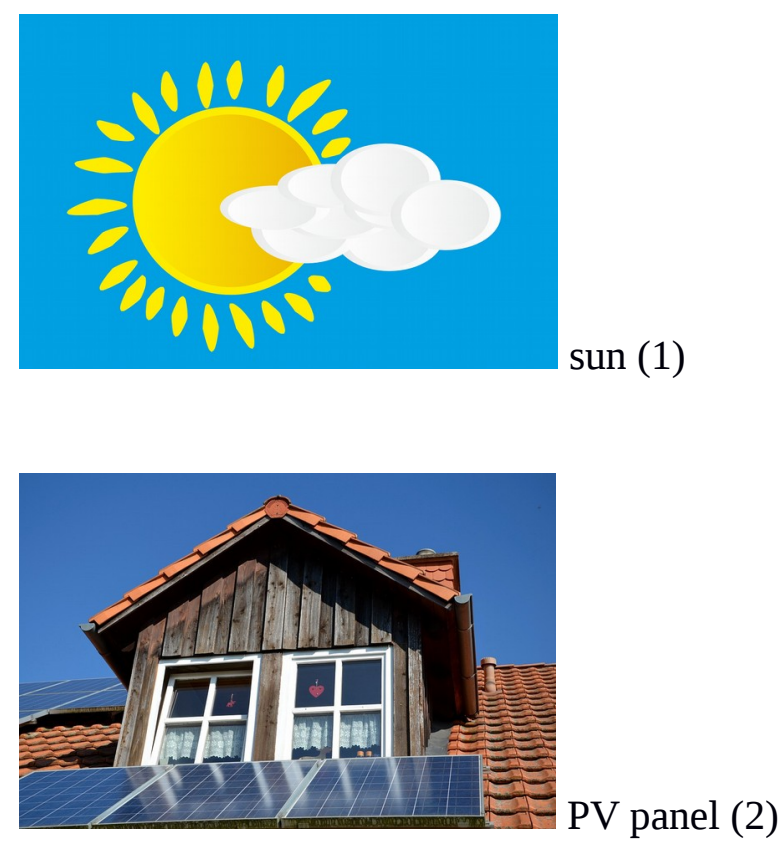

"The European Commission support for the production of this publication does not constitute an endorsement of the contents which reflects the views only of the authors, and the Commission cannot be held responsible for any use which may be made of the information contained therein." 

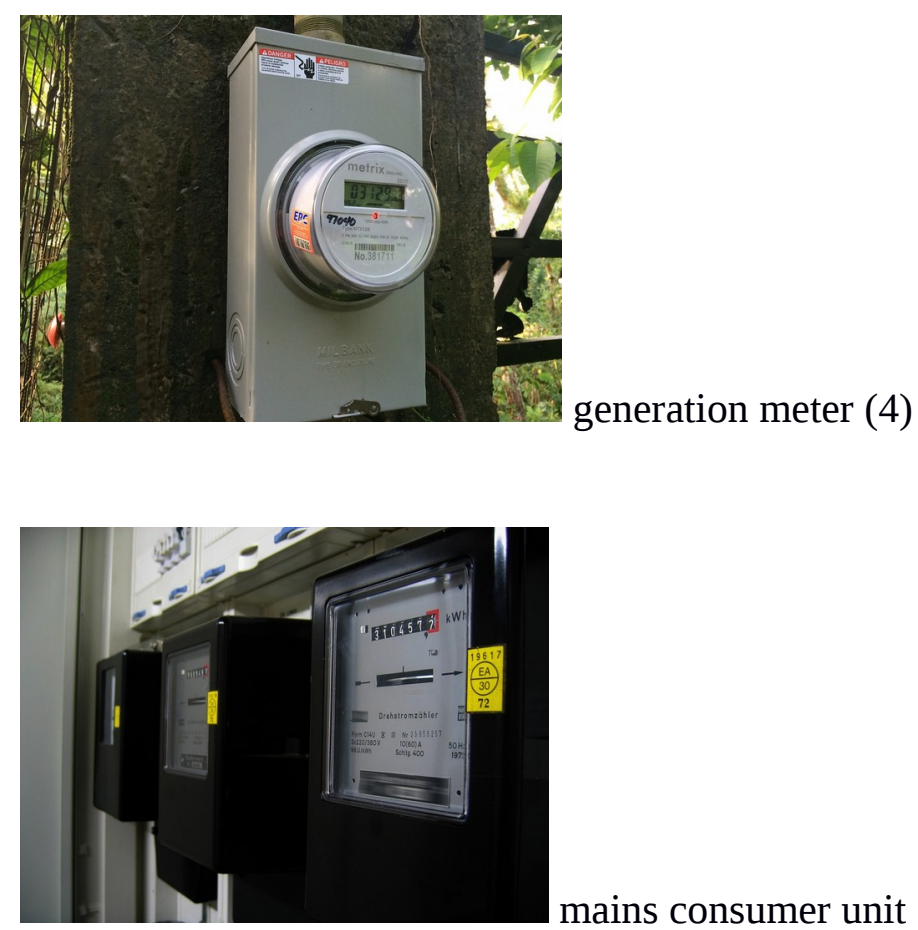

mains consumer unit (5)
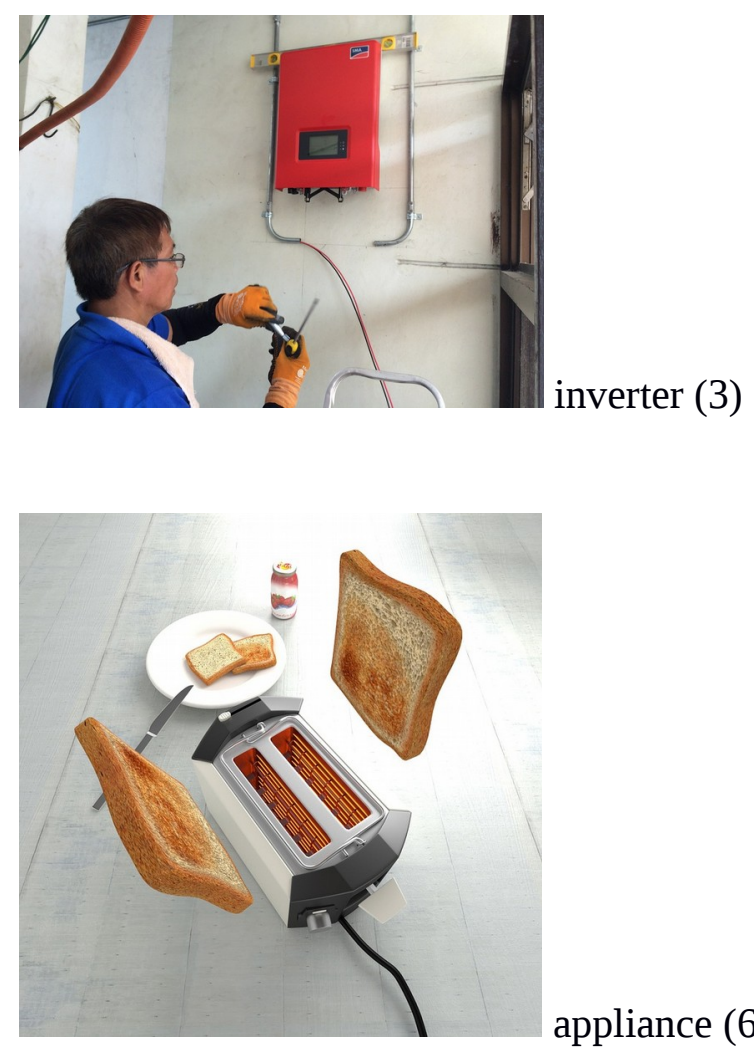

appliance (6) 


\section{Open Educational Resources for online course of}

Technical English for Renewable Energy

\section{Forum topic:}

What is a feed-in tariff? It was mentioned at the end of the video. 


\section{Open Educational Resources for online course of \\ Technical English for Renewable Energy}

\section{UNIT 6 PHOTOVOLTAIC ENERGY - Part 3}

\section{Watch the following video about PV panels.}

\section{https://www.youtube.com/watch?v=FIXQlATFELI}

\section{Decide whether the statements are true or false.}

1. The sun's energy can be converted into electricity in different ways. true

2. Recent advancements in technology have reduced the efficiency of PV panels. false

3. Photons are very small 'packets' of energy that make up light. true

4. A cell contains several panels. false

5. The positive and the negative layer of a cell create an electric field. true

6. When a lot of panels are connected, they are called a solar array. true

7. A solar array on the roof of a warehouse can supply electricity to two or three homes. false

8. PV panels have a lot of advantages, such as no emissions and no noise. true

What is the word or phrase defined? Use the list.

solar array absorbed

\section{semi-conductor}

electrons electric current photon

1. A ... is a number of solar panels connected into one system. (solar array)

2. A material that allows electricity to move through it easily when its temperature increases is called .... .

3. The smallest unit of light is a .... (semi-conductor)

4. The movement of electricity through a wire is an .... (photon)

5. When photons strike a solar panel, only a part of them will be taken in, or in other words, .... .

6. When photons strike a PV cell, their energy frees some ... in the semi-conductor.

(electrons) 

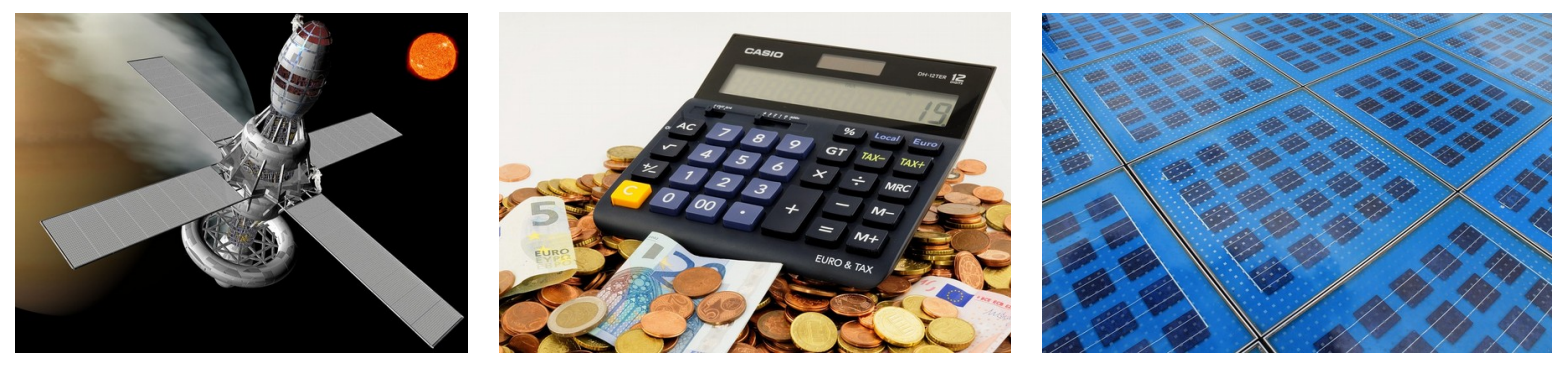

\section{Read the text below.}

\section{Photovoltaic Cells: Converting Photons into Electrons}

The solar cells that you see on calculators and satellites are also called photovoltaic (PV) cells, which as the name implies (photo meaning "light" and voltaic meaning "electricity"), convert sunlight directly into electricity. A module is a group of cells connected electrically and packaged into a frame (more commonly known as a solar panel), which can then be grouped into larger solar arrays, like the one operating at Nellis Air Force Base in Nevada.

Photovoltaic cells are made of special materials called semiconductors such as silicon, which is currently used most commonly. Basically, when light strikes the cell, a certain portion of it is absorbed within the semiconductor material. This means that the energy of the absorbed light is transferred to the semiconductor. The energy knocks electrons loose, allowing them to flow freely.

PV cells also all have one or more electric field that acts to force electrons freed by light absorption to flow in a certain direction. This flow of electrons is a current, and by placing metal contacts on the top and bottom of the PV cell, we can draw that current off for external use, say, to power a calculator. This current, together with the cell's voltage (which is a result of its built-in electric field or fields), defines the power (or wattage) that the solar cell can produce.

http://science.howstuffworks.com/environmental/energy/solar-cell1.htm

\section{Decide whether the statements are true or false according to the text.}

1. A PV module is the same as a solar panel.

true

2. A lot of PV modules grouped together are called a solar array.

true

3. At the moment, silicon is not a popular semi-conductor.

false

4. The semi-conductor gets the energy of all the light that strikes the solar cell. false

5. The energy of the light frees the electrons in the semi-conductor.

true

6. The electric field of the PV cell sends the electrons in a certain direction.

true

7. If we put a metal thing on one side of the PV cell, we can use the electrons running in it.

false 


\section{Complete the sentences with words from the text.}

The sunlight ... the PV cell.

(strikes)

1. The ... of the PV cell absorbs part of the sunlight, and takes its energy. (semiconductor)

2. The energy knocks ... free in the semi-conductor.

(electrons)

3. The freed electrons flow in one direction, creating an electric .... .

4. The metal ... on the two sides of the PV cell lead the electric current to different devices.

(contacts)

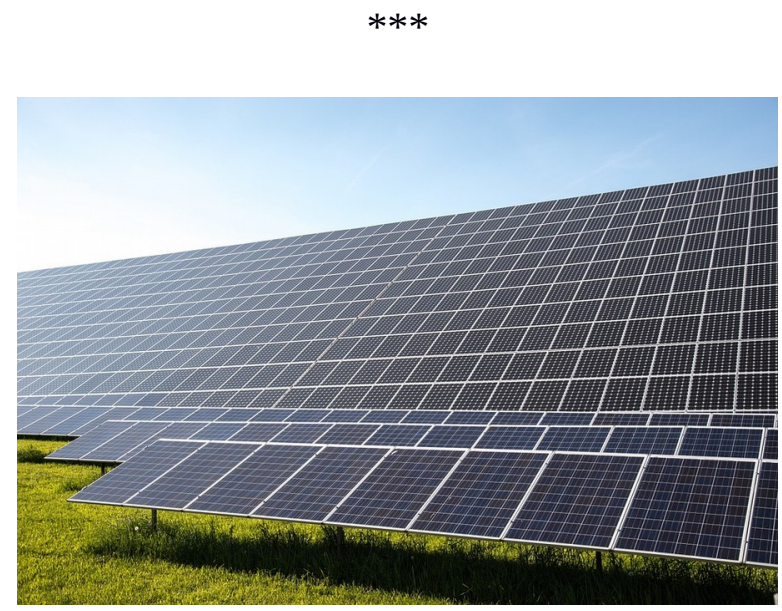

Put the steps of electricity generation into the correct order.

1. The sunlight strikes the PV cell.

2. The semi-conductor of the PV cell absorbs part of the sunlight, and takes its energy.

3. The energy knocks electrons free in the semi-conductor.

4. The freed electrons flow in one direction, creating an electric current.

5. The metal contacts on the two sides of the PV cell lead the electric current to different devices.

\section{Match the words with their meanings.}

1. grid power station to people

2. building-mounted

3. (public) utility companies

4. ranch

5. via

6. small-scale network of power lines that take electricity from the installed, put on a building electricity, water and gas companies

farm through including only a few things or people, limited in size 


\section{Open Educational Resources for online course of Technical English for Renewable Energy}

\section{Forum topic:}

The video describes where and how to install solar panels if you want to use solar energy in your home. Watch the video, and tell us which option would be the best for your home and why. Take the following things into account:

- size and orientation of your roof

- costs

- weather conditions in your area

https://www.youtube.com/watch?v=Ge lWfuLbPU 


\section{UNIT $7 \quad$ BIOMASS - Part 1}

Read the definition of biomass. Check the meaning of 'organic matter' if necessary.

Biomass is any organic matter that is used as a source of energy. Organic matter comes from living organisms such as plants and animals, and contains organically produced carbon.

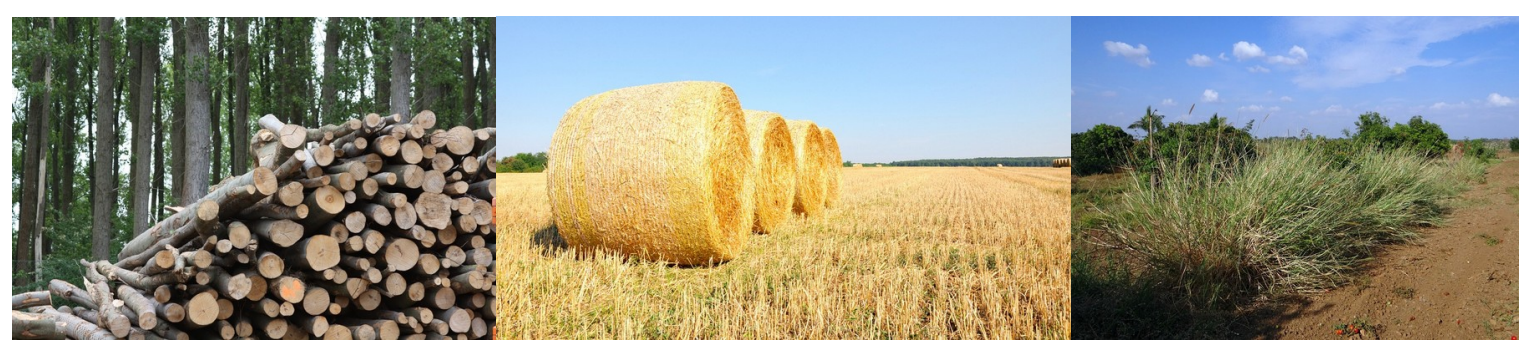

Which of these materials are considered organic matter?

$\begin{array}{ll}\text { wood } & \text { yes } \\ \text { clean air } & \text { no } \\ \text { rocks } & \text { no } \\ \text { agricultural crops } & \text { yes } \\ \text { animal waste } & \text { yes } \\ \text { metals } & \text { no } \\ \text { pure water } & \text { no } \\ \text { glass } & \text { no } \\ \text { dead leaves } & \text { yes }\end{array}$

\section{Read the text below.}

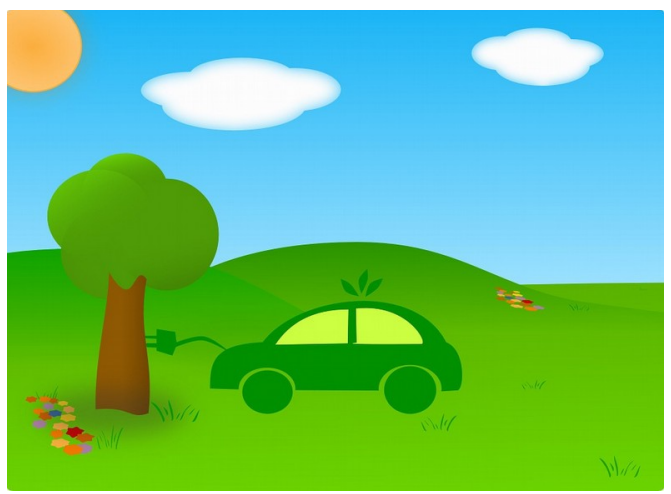

\section{What is biomass?}

To many people, the most familiar forms of renewable energy are the wind and the sun. But biomass (plant material and animal waste) is the oldest source of renewable energy, used since our ancestors learned the secret of fire.

"The European Commission support for the production of this publication does not constitute an endorsement of the contents which reflects the views only of the authors, and the Commission cannot be held responsible for any use which may be made of the information contained therein." 
Biomass is a renewable energy source not only because the energy in it comes from the sun, but also because biomass can re-grow over a relatively short period of time compared with the hundreds of millions of years that it took for fossil fuels to form. Through the process of photosynthesis, chlorophyll in plants captures the sun's energy by converting carbon dioxide from the air and water from the ground into carbohydrates-complex compounds composed of carbon, hydrogen, and oxygen. When these carbohydrates are burned, they turn back into carbon dioxide and water and release the energy they captured from the sun.

Source: http://www.ucsusa.org/clean_energy/our-energy-choices/renewable-energy/how-biomass-energy-works.html\#.VozQD6SVvb0

ancestors - a person's relatives who lived a long time ago

to capture - to catch

\title{
Are these sentences true or false on the basis of the text?
}

1. Most people associate renewable energy with solar and wind energy. true

2. Our ancestors think that biomass is the oldest source of renewable energy. false

3. Plant material and animal waste re-grow faster than fossil fuels. true

4. Fossil fuels were formed over a relatively short time. false

5. The energy in organic matter comes from the sun. true

6. When biomass is burnt, it releases carbon dioxide. true

\begin{abstract}
$* * *$
In the following pictures, you can see some organic matter used as sources of energy. Choose their names from the list below, and write the correct letter next to the picture.
\end{abstract}
a) saw dust
b) wood chips
c) wood pellets
d) corn stalks
e) straw

1.

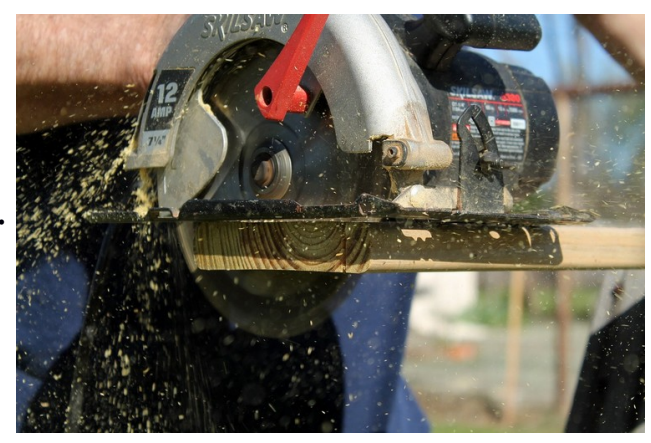

"The European Commission support for the production of this publication does not constitute an endorsement of the contents which reflects the views only of the authors, and the Commission cannot be held responsible for any use which may be made of the information contained therein." 
2.

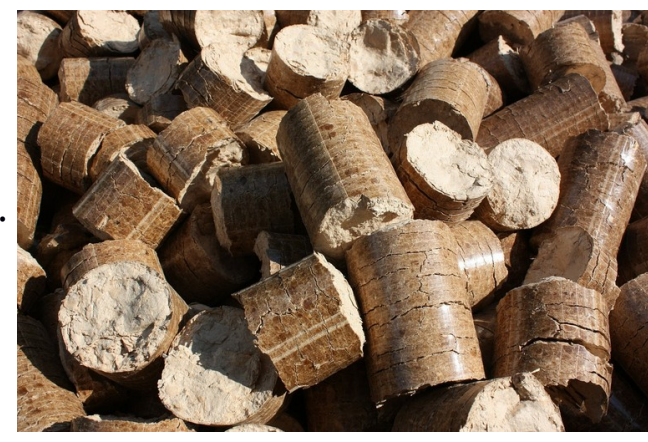

3.

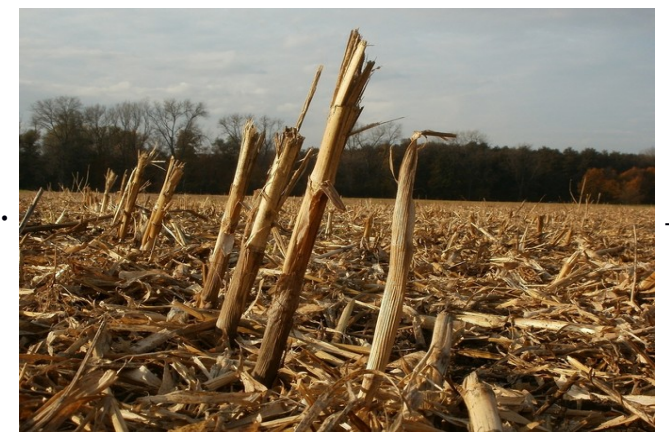

4.
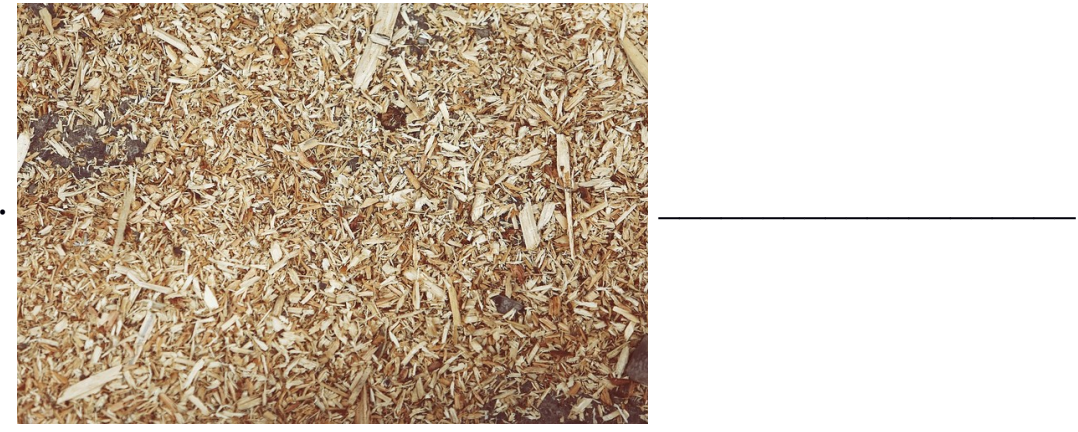

5.

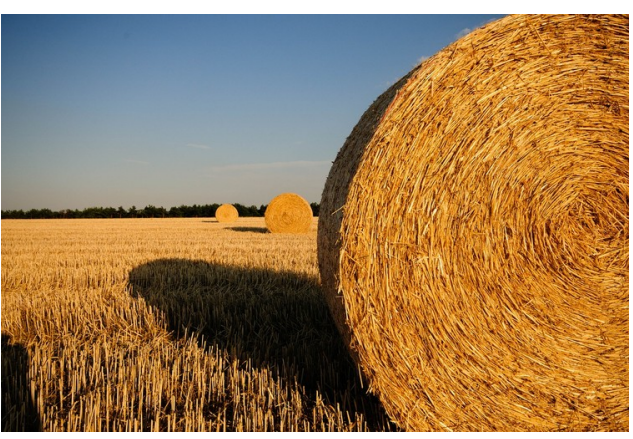

$* * *$ 


\section{Read the text below.}

\section{Sources of biomass}

The most common sources of biomass are:

- plants;

- animals;

- municipal solid waste.

\section{Plants}

The energy industry uses different wood products, such as wood chips, saw dust, scrap wood and forest residues (dead treas, branches). Certain parts of agricultural crops are also used for energy generation. Dried vegetation like straw, dry leaves, corn stalks, and all kinds of crop residues are suitable for this purpose.

However, there are also so called 'energy crops' that are grown specifically for use as fuel. They include fast growing trees, grasses and other non-woody energy crops, as well as aquatic plants such as algae and lake weeds.

\section{Animals}

Many farm animals produce wastes which can be used as energy sources. Some examples are poultry litter, and animal manures and slurries.

\section{Municipal solid waste (MSW)}

Municipal solid waste is commonly known as garbage (US) or rubbish (UK). It includes all kinds of everyday items that are thrown out by the public. It usually does not include industrial or agricultural wastes. MSW is generally collected in landfills. The rubbish is dumped into a hole or on the side of a hill, compacted by large machines, and then covered with a plastic sheet and several feet of dirt.

\section{Which category o fbiomass do these products belong to?}

Algae and lake weeds

everyday rubbish

corn stalks and other crop residues

animal manure

forest residues such as dead trees and branches

poultry litter energy crops

municipal solid waste

agricultural crops

animal waste

wood products

animal waste 


\section{Open Educational Resources for online course of \\ Technical English for Renewable Energy}

\section{Choose the correct answer.}

1. It ... millions of years for fossil fuels to form in rock and earth.
a) makes
b) takes (yes)
c) take
d) last

2. 'I am not familiar with this source of renewable energy.' means the same as ...

a) This source of renewable energy is not for my family.

b) I don't know anything about this source of renewable energy. (yes)

c) I have a good knowledge of this source of renewable energy.

d) My family doesn't use this source of energy.

3. Thousands of years ago, our ... burned wood to make fire.
a) relative
b) great-grandparents
c) ancestors (yes)
d) ancistors

4. Biomass can be re-grown in a ... short time.
a) quite
b) quiet
c) related
d) relatively (yes)

5. Photosynthesis is a process used by plants to ... light energy ... chemical energy.
a) convert; to
b) compare; into
c) convert; into (yes)
d) compare; to

6. When burning, biomass ... the energy stored in it.
a) releases (yes)
b) relases
c) let
d) allows

7. The most common sources of biomass are ...
a) plants and animals.
a) municipal solid waste.
b) agricultural residues.
c) wood products. (yes)
d) forest residues.

b) plants, animals and municipal liquid waste.

c) plants and municipal solid waste.

c) plants, animals and municipal solid waste. (igen)

8. Wood chips and saw dust are ... 
9. Algae can be used ...

a) for energy generation. (yes)

b) to collect dried vegetation.

c) to produce corn stalks.

d) as crop residues.

10. Many farm animal wastes, such as ..., can be used as energy sources.
a) poultry manures
b) poultry slurry
c) poultry litter (yes)
d) poultry scraps

These are the most important words of this unit. Check the meanings of the words or phrases that you do not know.

wood chips

saw dust

scrap wood

forest residues

branch of a tree

agricultural crops

dried vegetation

straw

corn stalks

crop residues

non-woody energy crops

aquatic plants

algae

lake weeds

animal waste

poultry litter

manure

municipal solid waste (MSW)

landfill

to dump

dirt

\section{Forum topic:}

Why are trees renewable and why are coal and oil not? 


\section{UNIT 8 BIOMASS - Part 2}

Watch this video about biomass once.

https://www.youtube.com/watch?v=dQ-cIVJuDks

Now, read the sentences below. Are they true or false on the basis of the video? If necessary, look up the new words in your dictionary, and you can also watch the video again.

1. Biomass can be processed into fuel or heat. true

2. Biomass is a carbon-neutral fuel. true

3. Biomass can support the rural economy. true

4. District heating can supply energy and hot water for one household. false

5. Wood is the most common type of biomass fuel. true

6. Wood logs are not easily available. false

7. Wood pellets need less storage and have a higher calorific value than logs. true

8. Biomass is a clean but not sustainable fuel source. false

Watch the video again, and fill in the gaps with the correct words from the list. There are 2 extra words.

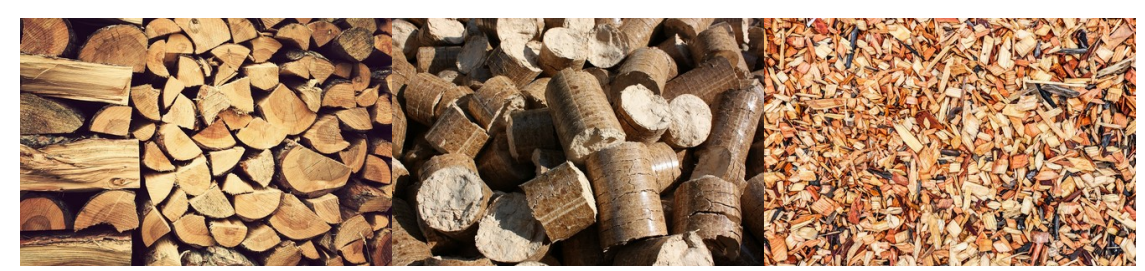
wood
18
pellets
boiler
8
automated
boilers
storage
advantage
inexpensive
expensive

According to the video, the most common type of biomass fuel in the UK is (wood). The three main forms of wood used in biomass (boilers) are logs, wood pellets and wood chips.

The main (advantage) to using logs in a boiler is that they are easily available. A fully loaded burn chamber can burn for up to in low demand. (18) hours when the system is

Wood (pellets) are manufactured from by-products from saw mills and other wood-processing industries. Advantages:

- They need less (storage) than logs or chips as they have a higher calorific value for the same volume. "The European Commission support for the production of this publication does not constitute an endorsement of the contents which reflects the views
only of the authors, and the Commission cannot be held responsible for any use which may be made of the information contained therein." 


\section{Open Educational Resources for online course of Technical English for Renewable Energy}

- Wood pellet boilers are generally fully (automated), with the pellets sucked by vacuum straight into the boiler from the store.

Wood chip is timber that has been shredded in a chipper.

Advantages:

- an easy fuel for automation: a screw-feed takes the chips from the store into the (boiler)

- the chip system is (inexpensive) to run.

These are the most important words for you to remember. Do you know their meanings in your language? If not, look them up in the dictionary.

biomass boiler

$\log$

to load

fully loaded

burn chamber

by-product

saw mill

wood processing

storage

calorific value

to shred timber

\section{Decide if the following statements are true on the basis of the text above.}

1. In the United Kingdom, most biomass comes from wood. T

2. If you fill the burn chamber of a boiler with logs, you don't need to reload it for a day. $\mathrm{F}$

3. Logs need less storage than chips. F

4. Both wood pellet and wood chip boilers can be fully automated. T

5. Wood pellets are transported into the boiler by a screw-feed. F

6. Wood chips are transported into the boiler by vacuum. F

\section{Read the text below.}

\section{How is biomass used?}

You can produce energy from biomass in different ways. You can use it directly to produce heat through combustion, or indirectly to convert it into various forms of biofuel.

Heat

Heat can be used to provide hot water for households, or to heat individual buildings or several households through district heating. 


\section{Open Educational Resources for online course of Technical English for Renewable Energy}

Heat can also be the source of electricity generation. Biomass can be burnt in biomass power plants, or in co-firing power plants. Co-firing means that two different materials are burnt at the same time. Biomass is usually added to coal, so no new plant has to be built to generate cleaner electricity.

\section{Biofuels}

Biomass can be converted into different biofuels in three ways: thermal, chemical and biochemical conversion. The forms of these biofuels can be solid, liquid or gas. The most common examples are bioethanol, biodiesel, biogas and wood pellets.

combustion - burning

district heating - a system in which one boiler heats a large number of buildings by sending hot water through pipes

solid - hard, not having the form of a gas or a liquid

liquid - material that can flow (e.g. water)

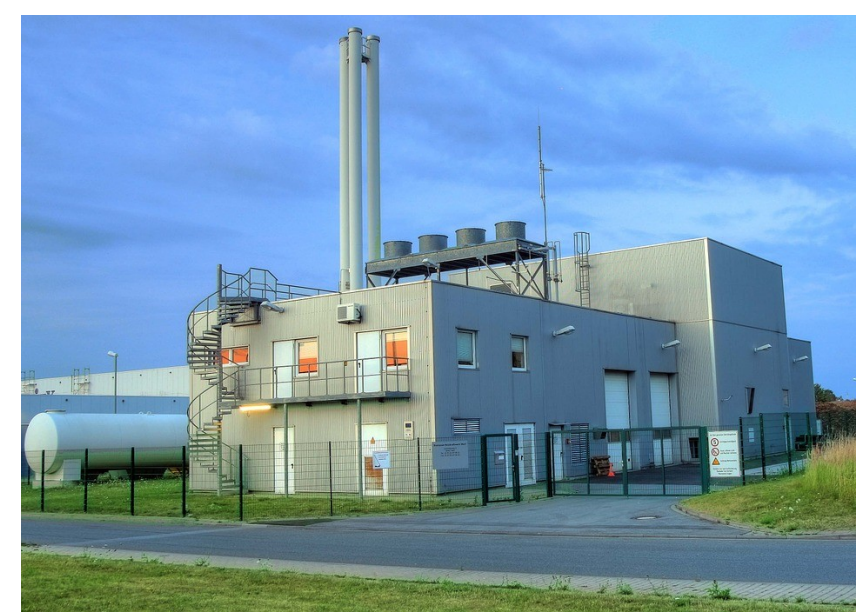

Biomass power plant in Werl, Germany

\section{Choose the best answer.}

1. Energy from biomass can be produced ...

a) in three ways.

b) directly to produce heat and indirectly to make biofuel. (yes)

c) through combustion.

d) by converting it into a biofuel.

2. 'Co-firing' means .... .

a) firing something with biomass

b) burning two different materials in the same power plant (yes)

c) burning coal in a power plant

d) burning something in a power plant 


\section{Open Educational Resources for online course of \\ Technical English for Renewable Energy}

3. A boiler is a device that

a) heats water for cooking.

b) heats water to heat a building.

c) heats water to heat a building or buildings, and provide hot water for household use. (yes)

d) burns biomass to generate electricity.

4. Which one is true?

a) Biogas is liquid biofuel.

b) Wood pellets are a common type of solid biofuel. (yes)

c) Biodiesel is biomass in gaseous form.

d) Bioethanol is an alcohol, and not a biofuel.

Here are the most important words of the text. Look them up in the dictionary if you don't know their meanings.

$\log$

combustion

district heating

biomass power plant

co-firing power plant (e.g. coal + biomass)

bioethanol

biodiesel

biogas

\section{Forum topic:}

According to the video, biomass is carbon-neutral. What is your opinion? Give reasons and examples. 


\section{Open Educational Resources for online course of \\ Technical English for Renewable Energy}

UNIT $9 \quad$ BIOMASS - Part 3

Watch this video about biomass and how electricity is made from it: https://www.youtube.com/watch?v=HZoPNJGi6ig

Read the sentences. Are they true or false on the basis of the video? Watch it again to decide.

1. The energy of the sun is absorbed by plants with photosynthesis, and released when they decompose or when they are burnt.

true

2. Plant waste from farms is collected and burnt to generate electricity. true

3. Animal waste is collected in small tanks, called digesters.

false

4. Digesters are filled with bacteria that convert waste into methane gas.

true

5. Methane cannot be captured from landfills.

false

6. Biomass must be used carefully to prevent greenhouse gas emissions.

true

Watch the video again, and complete the steps of electricity generation.

1. The waste is burnt to water.

2. The hot water creates

3. The of the steam spins a turbine.

4. The turbine powers a

5. The creates electricity. (generator)

Complete the text with the most suitable words. There is one extra word.

$\begin{array}{llll}\text { sugarcane } & \text { bioethanol } & \text { sugar } & \text { transesterification } \\ \text { fuel } & \text { pure } & \text { sweet } & \text { Europe }\end{array}$

Bioethanol is an alcohol made by fermentation, mostly from carbohydrates produced in ... (sugar) or starch crops such as corn, or ... (sugarcane). (...) Ethanol can be used as a... (fuel) for vehicles in its pure form, but it is usually used as a gasoline additive to increase octane and improve vehicle emissions. ... (Bioethanol) is widely used in the USA and in Brazil.

Biodiesel can be used as a fuel for vehicles in its ... (pure) form, but it is usually used as a diesel additive to reduce levels of particulates, carbon monoxide, and hydrocarbons from diesel-powered vehicles. Biodiesel is produced from oils or fats using ... (transesterification) and is the most common biofuel in ... (Europe). 


\section{Read the text about the wood pellet manufacturing process.}

\section{How are pellets made?}

Pellet mills can produce pellets from saw dust, wood chips, scrap wood and even full trees. These different forms of wood are put through a chipper or a hammer mill, which breaks them down into a consistent smaller size. Afterwards, wood chips are fed through a dryer to remove the moisture content of the raw material, especially in case of freshly cut wood.

After drying, the sawdust is pressed through dies at high pressure. A die is a metal container that gives sawdust the shape and diameter of a pellet. During this process, the sawdust gets very hot and releases its fibre that keeps the sawdust together.

When the hot, shaped sawdust is coming out of the die, it is cut into pieces of a certain length. Then it is cooled in a cooling tower. This is when the pellets become hard. After cooling, they are stored in large silos, then put into plastic bags or sold in bulk.

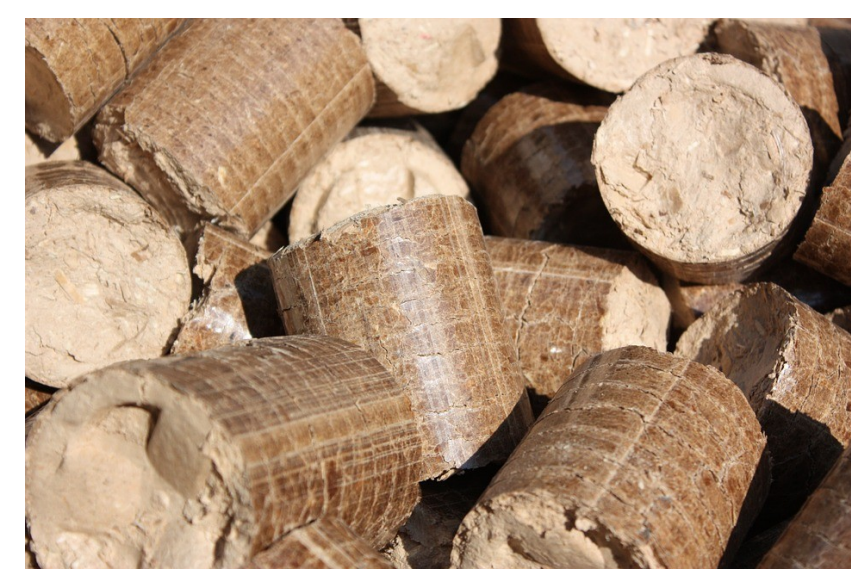

In what order are these machines used in a pellet plant before pellets reach the silo?
... chipper
... hammer mill
... dryer
... die
... cooling tower
6 silo

\section{Write the name of the machine that is described.}

It reduces the moisture content of the raw material: (dryer) It shapes saw dust into pellets: 


\section{Open Educational Resources for online course of Technical English for Renewable Energy}

It breaks wood down into smaller pieces:

It reduces the temperature of the pellets: (chipper/hammer mill)

(cooling tower)

\section{Forum topic:}

What makes algae an attractive source of biofuel? You can watch the following video about biofuels: https://www.youtube.com/watch?v=-ck3FYVNl6s 


\section{UNIT 10 WIND ENERGY - Part 1}

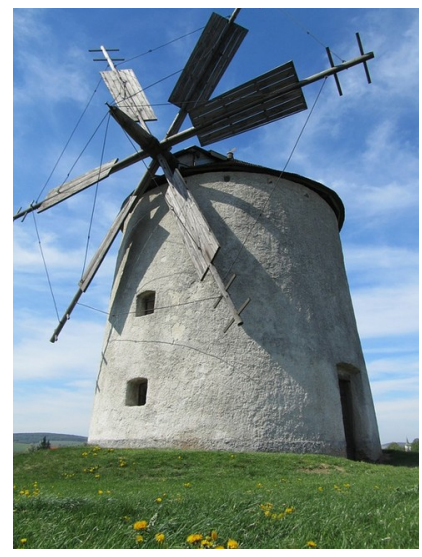

\section{Read the text below.}

\section{Wind Energy}

Wind power captures the natural wind in our atmosphere and converts it into mechanical energy, then electricity. People started using wind power centuries ago with windmills, which pumped water, ground grain, and did other work.

Today's wind turbine is a highly evolved version of a windmill. Modern wind turbines harness wind's kinetic energy and convert it into electricity. Most wind turbines have three blades and sit atop a steel tubular tower, and they range in size from 80 -foot-tall turbines that can power a single home to utility-scale turbines that are over 260 feet tall and power hundreds of homes.

Wind is a type of renewable energy, and there are three major types of wind power, namely:

- Utility-scale wind, wind turbines larger than 100 kilowatts are developed with electricity delivered to the power grid and distributed to the end user by electric utilities or power system operators;

- Distributed wind, which uses turbines of 100 kilowatts or smaller to directly power a home, farm or small business as its primary use;

- Offshore wind, which are wind turbines erected in bodies of water around the world, but not yet in the United States.

http://www.awea.org/Resources/Content.aspx?ItemNumber=900 
Which type of wind power can you see in the picture? Find the words in the text above.

distributed wind:

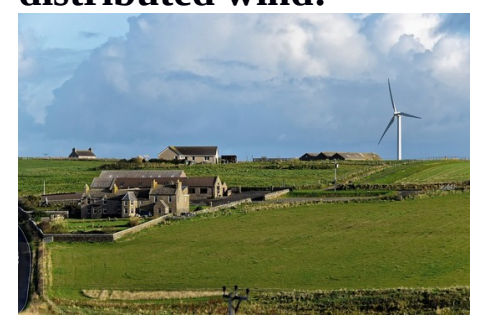

utility-scale wind:

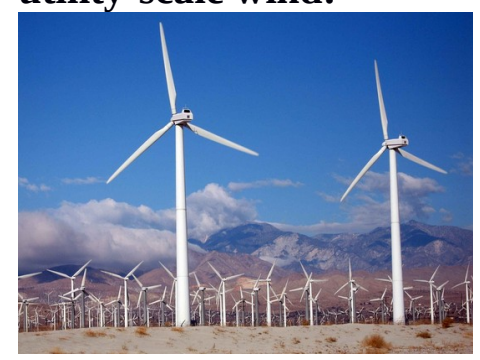

offshore wind:

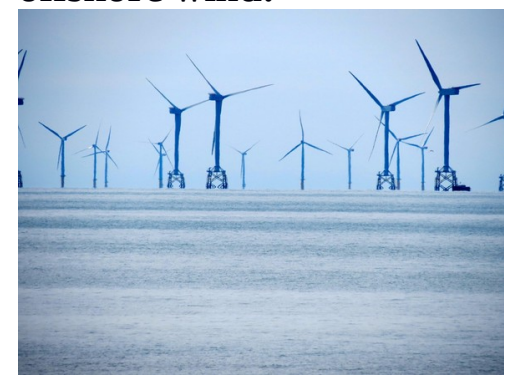

These are the most important words. Look them up in a dictionary if necessary. mechanical energy

kinetic energy

windmill

wind turbine

to harness

blade

utility-scale wind power / big wind power

home-based wind power / distributed wind power

offshore wind power 


\section{Choose the correct answer(s). Sometimes two answers are correct.}

1. A wind turbine usually consists of

- three blades

- a tube-shaped tower

yes

- three wings

yes

no

2. Utility-scale wind farms deliver electricity

- directly to the end-user no

- to the power grid yes

- through the power grid to utility companies yes

3. Home-based wind turbines are also called

- distributed wind power

yes

- big wind power

no

- utility-scale wind power

no

\section{Watch this video.}

https://www.youtube.com/watch?v=niZ cvu9Fts

Decide whether the statements are true or false according to the video.

1. Sailboats and windmills used wind thousands of years ago. true

2. Wind is air in emotion. false

3. The air of the water gets warm more quickly than over the land. false

4. In 2010, exactly $2 \%$ of US electricity came from wind power. false

5. Wind turbines harness the electric energy of moving air. false

6. Wind farms are different from solar farms as they do not connect individual wind turbines together.

false

\section{Match the words with their definitions.}

predictable

uneven temperatures

to harness

kinetic energy

solar array

to capture

wind happening in a way that is expected changing temperatures to control it in order to use its power energy involving movement a number of connected solar panels to catch, to harness air in motion 
Complete the following short text with the correct words. Look up the new words in a dictionary.
shaft
windmill
generator
blades

A wind turbine is the modern advancement of the (windmill). The wind turns the (blades), which spin a (shaft). The shaft connects to a (generator), which makes electricity.

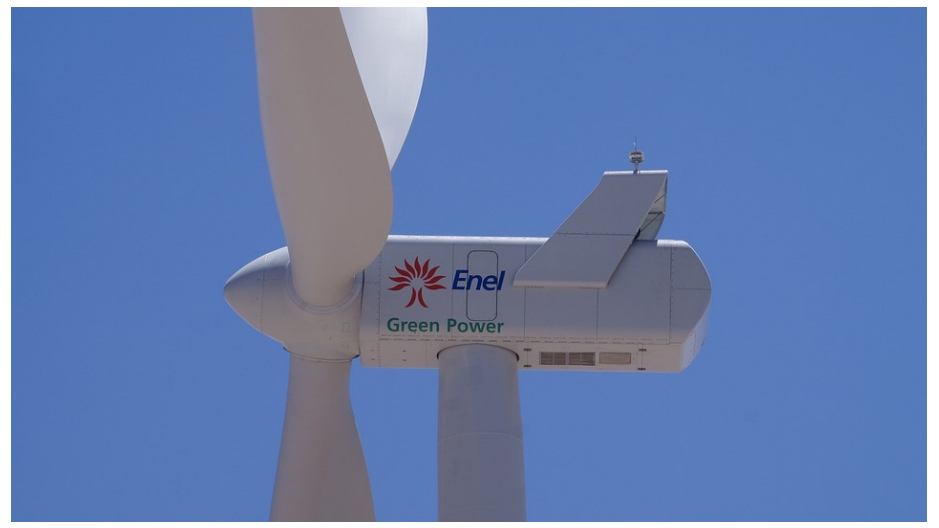

In the following text, you can read about wind turbines in more detail. Don't use a dictionary.

\section{How wind turbines work}

Wind turbine blades spin because of lift, the same force that allows airplanes to fly. If the blades are all oriented in the same direction, they will start to spin. The blades are attached to a hub, which spins as the blades turn. Most modern wind turbines have three blades. The blades and the hub together are called the rotor.

As the rotor turns, it spins a drive shaft, which is connected to a generator inside the housing at the top of the tower. The housing is called the nacelle. The spinning generator produces electricity because it converts the mechanical energy of moving wind into electrical energy. Between the spinning rotor and the generator, there is usually a gearbox to help the generator spin fast enough to make electricity.

The amount of electricity that a turbine is able to produce depends on the diameter of the rotor and the speed of the wind that propels the rotor. Wind turbines are often grouped together in wind farms to produce large amounts of electricity. Some wind farms have only a couple of wind turbines, but the largest wind farms are made up of hundreds and hundreds of wind turbines. 
Decide whether the statements are true or false according to the text.

Both the blades and the hub can spin.

true

The blades and the shaft together are called a rotor.

false

The housing of the wind turbine is called a nacelle.

true

The nacelle contains a drive shaft, a gearbox and a generator.

true

The role of the gearbox is to make the speed of the shaft lower.

false

The diameter of the rotor does not influence the amount of electricity produced.

false

When wind turbines are connected, they are called a wind farm.

true

Here are the most important words. Now, you can check their meanings in a dictionary. to spin / to turn

lift

force

to attach

hub

rotor

drive shaft

generator

nacelle

gear

gearbox

diameter

to propel

wind farm

Forum topic:

What can be the advantages of using wind turbines to generate electricity? 


\section{UNIT 11 WIND ENERGY - Part 2}

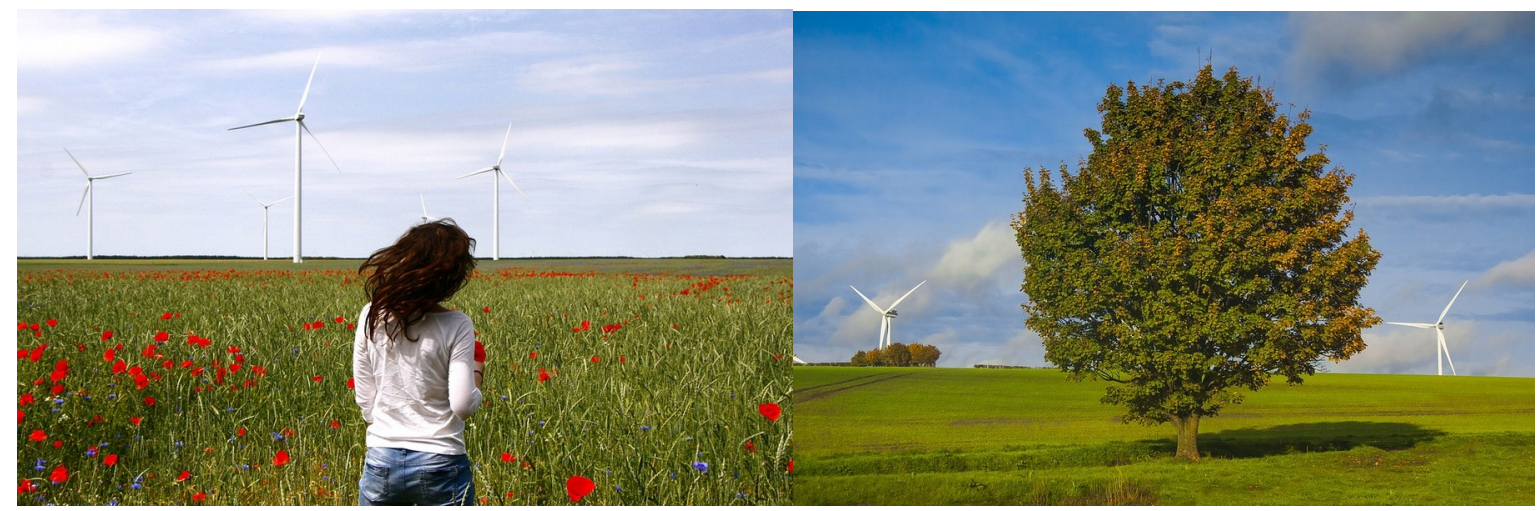

The website of The Office of Energy Efficiency and Renewable Energy (USA) lists the following advantages of wind power. Match them to the sentences by writing the correct number in the right place.

1 Wind power is cost-effective.

2 It's sustainable.

3 Wind is a domestic source of energy.

4 Wind turbines can be built on existing farms or ranches.

5 It's a clean fuel source.

6 Wind creates jobs.

- ... (5) Wind energy doesn't pollute the air like power plants that rely on burning fossil fuels, such as coal or natural gas.

- ... (3) The nation's wind supply is abundant. If we use wind, we don't need to import so many fossil fuels.

- ... (2) For as long as the sun shines and the wind blows, the energy can be harnessed to send power across the grid.

- ... (1) It is one of the lowest-priced renewable energy technologies available today, costing between four and six cents per kilowatt-hour, depending upon the wind resource and the particular project's financing.

- ... (4) The best wind sites are found in rural areas. Farmers and ranchers can continue to work the land because the wind turbines use only a fraction of the land. Wind power plant owners make rent payments to the farmer for the use of the land, providing landowners with additional income.

- ... (6) In 2014, the wind sector invested more than $\$ 8$ billion of private capital in the U.S. economy to build projects and employed more than 73,000 workers. 


\section{Match the words to their meanings.}

$\begin{array}{ll}\text { domestic } & \text { national, not foreign } \\ \text { abundant } & \text { more than enough } \\ \text { grid } & \text { network of power lines } \\ \text { to harness } & \text { to control in order to use its power } \\ \text { rural areas } & \text { areas outside cities, the countryside } \\ \text { a fraction of sg } & \text { a small part of sg ( } 1 / 4 \text { is a fraction) }\end{array}$

\section{Decide whether the statements are true or false according to the text above.}

1. Coal-fired power plants pollute the air more than wind turbines. true

2. The wind supply of the US is abundant. true

3. Wind is the cheapest energy source in the US today. false

4. Farmers get additional income from selling their lands to wind power companies.

5. In 2014, the US wind sector provided nearly 73,000 jobs. false

Watch the following video about how wind turbines work. https://www.youtube.com/watch?v=tsZITSeQFR0

Now, watch the video again and decide whether the statements are true or false.

1. Old windmills use the same principle as today's wind turbines. true

2. Blowing air spins the blade because the air pressure is the same on both sides of the blade.

false

3. On the top of the turbine, there's a weathervane.

true

4. The weathervane is connected to a computer that always turns the turbine into the wind.

true

5. The shaft turns very fast.

false

6. The gearbox reduces the rotation of the shaft.

false

7. Even a small wind farm can provide thousands of homes with energy.

true

\section{Match the words with their meanings.}

air pressure the force that the air puts on the blade

uneven

weathervane

shaft

gearbox

revolution

$$
\text { not equal, changing }
$$

metal object on the roof to show which way the wind is blowing from long pole or rod several wheels with pointed parts on the edges connected together movement in a circle around a central point 
What can you see in the pictures? Write their names in the spaces.

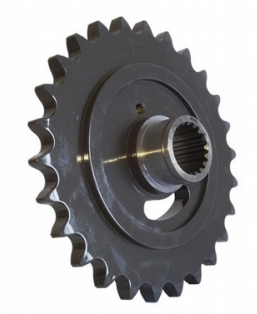

gear

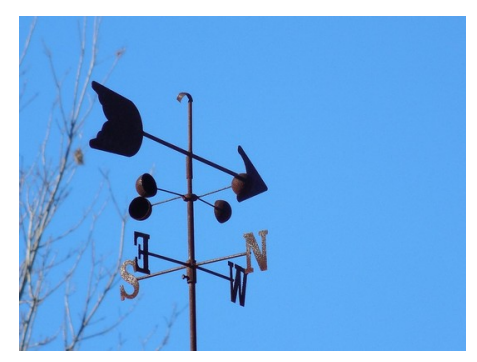

weathervane

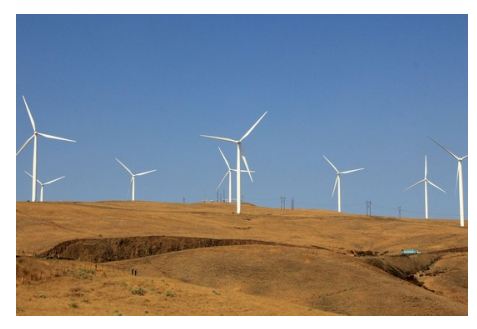

wind farm

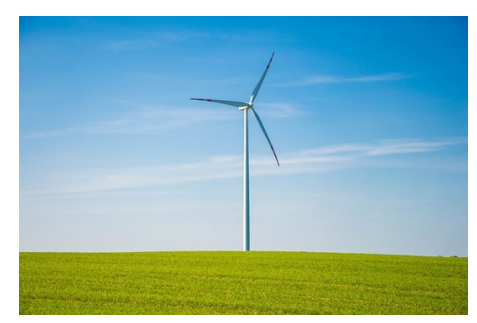

wind turbine

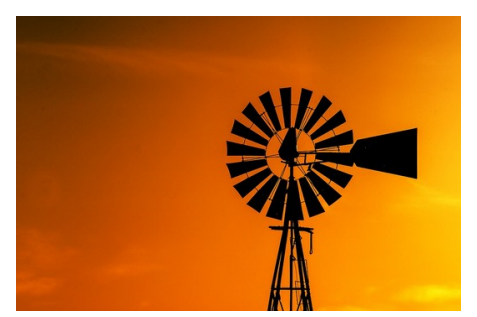

windmill 


\section{Forum topic:}

What can be the disadvantages of using wind turbines to generate electricity? 


\section{UNIT 12 WIND ENERGY - Part 3}

The website of The Office of Energy Efficiency and Renewable Energy (USA) lists the following disadvantages of wind power. Match them to the sentences by writing the correct number in the right place.

1. Wind power must still compete with conventional generation sources on a cost basis.

2. Turbines might cause noise and aesthetic pollution.

3. Turbine blades could damage local wildlife.

4. Good wind sites are often located in remote locations, far from cities where the electricity is needed.

5. Wind resource development might not be the most profitable use of the land.

\section{Challenges of Wind Power}

- ... (1) Depending on how energetic a wind site is, the wind farm might not be cost competitive. Even though the cost of wind power has decreased dramatically in the past 10 years, the technology requires a higher initial investment than fossil-fueled generators.

- ... (4) Transmission lines must be built to bring the electricity from the wind farm to the city.

- ... (5) Land suitable for wind-turbine installation must compete with alternative uses for the land, which might be more highly valued than electricity generation.

- ... (2) Although wind power plants have relatively little impact on the environment compared to conventional power plants, concern exists over the noise produced by the turbine blades and visual impacts to the landscape.

- ... (3) Birds have been killed by flying into spinning turbine blades.

Most of these problems have been resolved or greatly reduced through technological development or by properly siting wind plants.

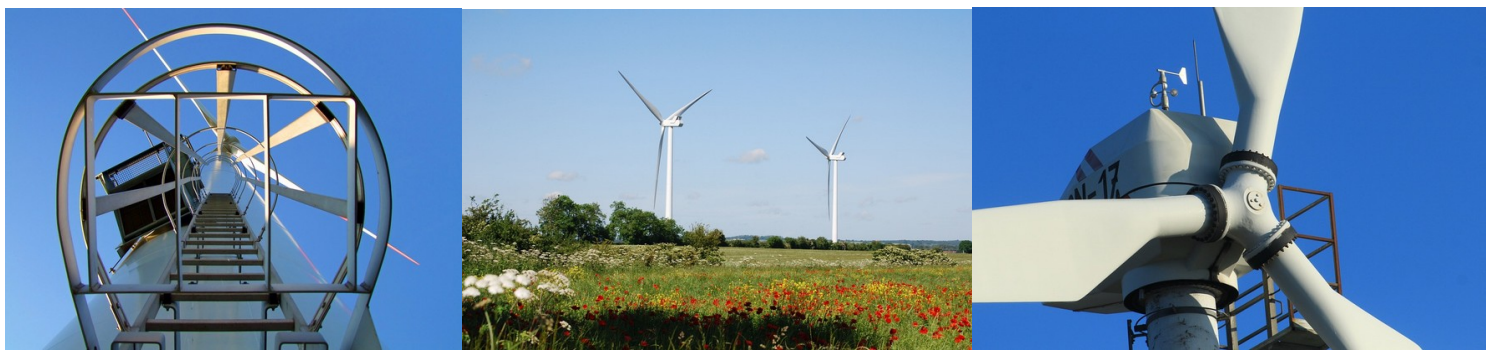

Match the words with their meanings.

$\begin{array}{ll}\text { even though } & \text { although } \\ \text { to decrease } & \text { to fall } \\ \text { to require } & \text { to need } \\ \text { to resolve } & \text { to solve, to find a solution } \\ \text { concern } & \text { worry }\end{array}$

"The European Commission support for the production of this publication does not constitute an endorsement of the contents which reflects the views only of the authors, and the Commission cannot be held responsible for any use which may be made of the information contained therein." 
The following words and phrases are connected to money. Match them with their definitions.
cost
cost-effective
costly
the amount of money needed to buy or do something
cost-competitive
good value for the money paid
expensive
cheap compared to other similar things

Read the text again, and decide whether the statements are true or false.

More money is needed to build a wind farm than a coal-fired power plant. true

Wind farms are usually built near cities. false

Agricultural cultivation of lands is not as important as wind farms. false

Some people are worried about noise and aesthetic pollution of wind farms. true

Several birds have died due to the spinning blades of wind turbines. True

These are the most important words to remember. Please check their meanings in your dictionary if necessary.

to compete

competitive

initial investment

site

in remote locations

agriculture

cultivation

profitable

noise pollution

aesthetic / visual pollution

Watch the following video that summarizes the things you have learnt about wind energy.

https://www.youtube.com/watch?v=8PE69jcleKg

Watch the first part of the video again (from 0:00 to 2:58), and choose the correct answer.

We have harnessed wind power ...
a) for a thousand year.
b) for thousands of years. yes

The generator is ... of a wind turbine.
a) in the nacelle
yes

b) in the hub

"The European Commission support for the production of this publication does not constitute an endorsement of the contents which reflects the views
only of the authors, and the Commission cannot be held responsible for any use which may be made of the information contained therein." 


\section{Open Educational Resources for online course of Technical English for Renewable Energy}

One wind turbine needs less than ... of land.
a) one acre
yes

b) one square metre

The United Kingdom is ... of Europe.

a) the least windy country

b) the windiest country

One wind turbine can generate as much electricity as ...

a) 1,600 solar panels.
b) 16,000 solar panels.

A wind turbine can work for
a) 25 years.
b) 15 years.

yes

Wind turbines don't need water to generate electricity, ...

a) unlike solar panels.

b) unlike coal, gas and nuclear power plants.

Wind turbines ...
a) cause much fewer bird fatalities than buildings.
yes
b) are noisier than a vacuum cleaner at a distance of 400 metres from the base.

\section{Forum topic:}

Which one would be better for the world: supplying all our energy from solar or wind power? 
